\title{
Genetic Variability and Characters Association of Hot Pepper (Capsicum annuum L.) Genotypes Tested under Irrigation in Northern Ethiopia
}

\author{
Fasikaw Belay ${ }^{1}$, Berhanu Abate ${ }^{2} \&$ Yemane Tsehaye $^{3}$ \\ ${ }^{1}$ Horticulture Department, Axum Agricultural Research Center, Axum, Ethiopia \\ ${ }^{2}$ Hawassa University, School of Plant and Horticultural Sciences, Hawassa, Ethiopia \\ ${ }^{3}$ Department of Crop and Horticultural Science, Mekelle University, Mekelle, Ethiopia \\ Correspondence: Fasikaw Belay, Horticulture Department, Axum Agricultural Research Center, P.O. Box 230, \\ Axum, Ethiopia. E-mail: fasikawbelay79@gmail.com
}

Received: May 20, 2020 Accepted: June 9, 2020 Online Published: June 17, 2020

\begin{abstract}
Hot pepper production in most areas of Ethiopia especially in Tigray region is constrained by shortage of varieties, the prevalence of fungal and bacterial as well as viral diseases. Sixty-four hot pepper genotypes were evaluated to obtain the extent of genetic variability, association among characters. The experiment was laid out using $8 \times 8$ simple lattice design at Axum Agricultural Research center in 2017/18. Data were collected for 19 agronomic characters and analysis of variance revealed significant differences $(\mathrm{p}<0.01)$ among the genotypes for all characters. Fruit yield ranged from 0.8 to $4.5 \mathrm{t}$ ha- 1 with a mean of $2.7 \mathrm{t}$ ha- 1 . The genotypic coefficient of variation (GCV) and phenotypic coefficient of variation (PCV) ranged from 3.57and 3.84 for days to maturity to 42.4 and $42.9 \%$ for average single fruit weight. All the traits had moderate to very high broad sense heritability while genetic advance as percent of mean (GAM) ranged from 8.34 for days to maturity to $85 \%$ for average single fruit weigh. High heritability coupled with high GAM was obtained for average single fruit weight, fruit length, dry fruit yield per plant, fruit diameter and thousand seed weight reflecting the presence of additive gene action for the expression of these traits and improvement of these characters could be done through selection. Fruit yield per hectare had positive and highly significant phenotypic and genotypic correlations with dry fruit yield per plant, average single fruit weight, fruit pericarp thickness, thousand seed weight, fruit diameter and fruit length, but it had negative and highly significant genotypic and phenotypic correlations with days to maturity. Estimates of genotypic and phenotypic direct and indirect effects of various characters on fruit yield showed that dry fruit yield per plant, fruit pericarp thickness had the highest positive direct contribution to fruit yield indicating that selection based on these characters will improve fruit yield. In conclusion, the research results showed the presence of significant variations among genotypes for agro-morphology traits. Therefore, it is recommended further evaluation of genotypes or hybrids that exhibited highest yield, quality and disease resistance in subsequent breeding programs to improve the productivity of the crop.
\end{abstract}

Keywords: vegetable crop, genetic correlation, additive gene, direct effect, genetic advance, heritability

\section{Introduction}

The genus Capsicum belongs to the family Solanaceace and it includes 30 species, including five domesticated and commercially cultivated species (C. annuum L., C. baccatum L., C. chinensis Jacq., C. frutescence L. and C. pubescence ) (Dagnoko et al., 2013). However, from the five-domesticated species of the genus C. annuum L. is the most widely cultivated species worldwide (Pickersgill, 1997). It is the world's most important vegetable after tomato and used as fresh, dried or processed products, as vegetables and spices or condiments (Berhanu et al., 2011). Nutritionally, hot pepper like any other Capsicum species is rich in vitamin A and C, calcium, phosphorus and potassium. It has been reported that peppers are highly appreciated for their spicy flavor and nutritional value. Currently, it is produced in many parts of the country, because food is tasteless without hot pepper for most Ethiopians. The crop is also one of the important vegetables that serve as the source of income particularly for smallholder producers in many parts of rural Ethiopia (Berhanu et al., 2011; Shimeles, 2018). Moreover, hot pepper contributes $40-60 \%$ to the household income (Shimeles, 2018). 
According to CSA (2017) the national average yields of hot pepper are $6.3 \mathrm{t}$ ha-1 for green pod and $1.8 \mathrm{t}$ ha- 1 for the dry pod, which is far below the dry pod yield (2.5-3.7 tha-1) of improved varieties harvested at research fields of Ethiopia (MoANR, 2016) and world average yield of 3 - 4 tha-1 (FAO, 2015). The productivity of the crop is low due to many limiting factors such as shortage of adapted high yielding varieties, using unknown seed sources and poor-quality seeds, poor irrigation system, lack of information on soil fertility, the prevalence of fungal and bacterial as well as viral diseases, lack of awareness on existing improved technologies and poor marketing system.

In the past decades, diverse pepper genotypes $(>300)$ were introduced from different regions of the world (Fekadu et al., 2008) adding to the diversity of the crop in Ethiopia. However, Ethiopia has less benefited from research activities although some research centers are working on hot pepper variety development, which mainly focused on adaptation and release of locally adapted varieties. For efficient and effective breeding work investigation and better understanding of the variability of existing genotypes is essential. Very few studies have been conducted on hot pepper genetic variability using morphological traits (Berhanu et al., 2011; Shimeles et al., 2016; Abrham et al., 2017 and Birhanu, 2017).

Effectiveness of selection depends on the amount of variability, heritability and genetic advance, interrelations among themselves and genetic divergence present in the genetic material for yield and yield related characters. Hence, developing of varieties with the desired traits has a significant contribution to increase the yield of hot pepper in the region. Therefore, the first step in the development of varieties is assessing the genetic variability of available genotypes for the characters of interest. Similarly, information on the extent and nature of interrelationship among plant characters' help formulating efficient index selection and the relative contribution of various components traits to yield (Singh, 1993). Besides, knowledge of the naturally occurring diversity in a population helps identify diverse groups of genotypes that can be useful for the breeding program. Greater the variability in a population, greater the chance for an effective selection of desirable types (Vavilov, 1951). Therefore, assessment of variability, association and heritability of traits in hot pepper genotypes in case of Central zone of Tigray agro-ecology is essential for planning an appropriate breeding strategy for genetic improvement of the crop. Hence, the present study was undertaken with the objectives to estimate phenotypic and genotypic variations, heritability and expected genetic advance of agronomically important traits in the hot pepper genotypes, to assess the extent of associations among yield and yield related traits and to identify the most yield predicting traits.

\section{Materials and Methods}

Experimental Site: The study was conducted under irrigation at Axum Agricultural Research Center (AxARC) experimental field, Mereb Lekhe District, in the central zone of Tigray, northern Ethiopia during 2017/18 cropping season. The site is located at about $1041 \mathrm{kms}$ away from Addis Ababa and $67 \mathrm{~km}$ to the north of Aksum town, at $14 \mathrm{o} 25^{\prime} 26^{\prime \prime}$ and 14018'48" N latitude, and 38o 42'15" and 38048'30" E longitude with an altitude of 1390 m.a.s.l. (Figure 1). The site is found in semi-arid tropical belt of Ethiopia with "kola" agro climatic zone and the rainy season is mono - modal concentrated in one season from late July to early September and receives from 400 - 600 $\mathrm{mm}$ of rain fall per annum. The mean minimum and maximum temperatures ranged from $13.30 \mathrm{C}$ to $33.70 \mathrm{C}$, respectively. The soil texture of the specific site of the study area is sandy clay loam textural class with bulk density of $1.7 \mathrm{~g} \mathrm{~cm}-3$, very low in organic carbon $(0.7 \%)$ with an alkaline $\mathrm{pH}$ of 8.2. 


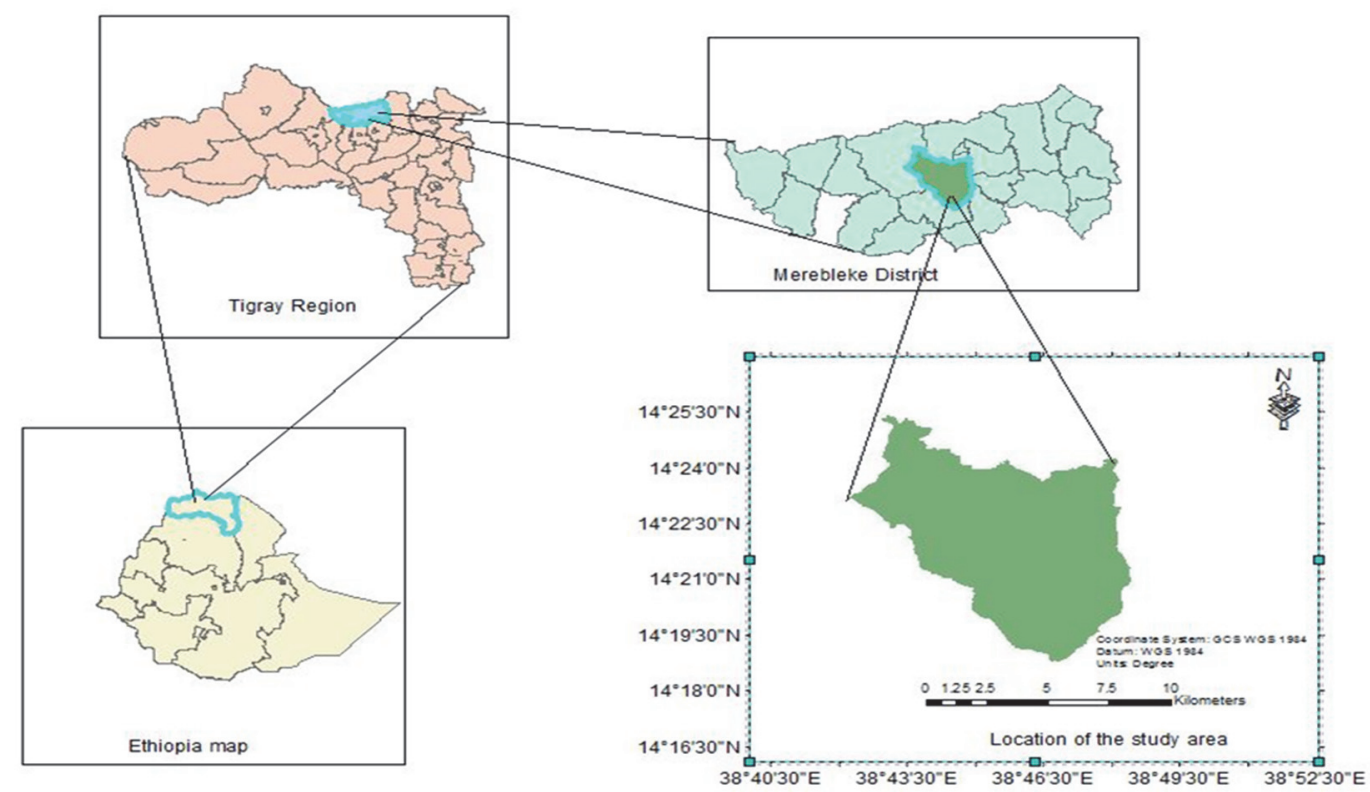

Figure 1. Geographical location of the study area showing Ethiopia, Tigray region, Mereb Leke District and specific location of the experimental site

Experimental Materials: Sixty-three local hot pepper Ethiopian landraces along with one released variety Mareko fana as a check were used in this study. The landraces were collected from different agro-ecologies of varying altitude, rainfall, temperature, and soil type by the Ethiopian Biodiversity Institute (EBI), Shire Maitsebri Agricultural Research Center (SMARC) and Melkassa Agricultural Research Center (MARC). The accession numbers and source of the genotypes are shown in Table 1.

Experimental Design: The experiment was laid out in $8 \times 8$ simple lattice design with two replications. The experimental materials were planted at Axum Agricultural Research Center main research site during 2017/2018 cropping season under irrigation. Seeds of each hot pepper genotypes were sown in seed bed of $0.6 \mathrm{~m} 2$ (3 rows, $0.2 \mathrm{~m}$ spacing between rows, $1 \mathrm{~m}$ row length) during October 2017 to raise seedlings. Seedlings were transplanted to main field 48 days after seed sowing i.e. when the seedlings attained $15 \mathrm{~cm}$ height. Each genotype was planted in the main field in a plot size of $8.4 \mathrm{~m} 2(2.8 \mathrm{~m} \mathrm{x} 3 \mathrm{~m})$. Each plot consisted of four rows of $3 \mathrm{~m}$ length with inter and intra-row spacing of $0.7 \mathrm{~m}$ and $0.3 \mathrm{~m}$, respectively, containing a total of 40 plants. Each incomplete block and replication was spaced 1 and 1.5 meters, respectively. The middle two rows were used for data collection leaving the two rows as borders. Fertilizer, Di-ammonium phosphate (DAP) as a source of Phosphorus was applied at the rate of $200 \mathrm{~kg}$ ha-1 during planting and nitrogen fertilizer was applied in the form of Urea at the rate of $150 \mathrm{~kg}$ ha1 in splits, half during transplanting and the rest as side dressing at 45 days after transplanting. Watering was made following furrow irrigation at 7days interval (AxARC, 2016) was used. Weeding, hoeing and other field management and crop protection activities were done as required.

Table 1. Hot pepper accessions tested under furrow irrigation in northern Ethiopia, their local name, area of collection, origin and sources

\begin{tabular}{|c|c|c|c|c|c|c|c|c|c|}
\hline NO. & $\begin{array}{l}\text { Accession } \\
\text { Name }\end{array}$ & Local Name & $\begin{array}{l}\text { Site of } \\
\text { Collection }\end{array}$ & Sources & NO. & $\begin{array}{l}\text { Accession } \\
\text { Name }\end{array}$ & Local Name & $\begin{array}{l}\text { Site of } \\
\text { collection }\end{array}$ & Sources \\
\hline 1 & Acc-1 & Berebere Hormat & Raya Kobo & Amhara & 33 & $\begin{array}{l}\text { Acc- } \\
229701\end{array}$ & Hulet Ejenese & $\begin{array}{l}\text { Misrak } \\
\text { Gojam }\end{array}$ & Amhara \\
\hline 2 & Acc-2 & $\begin{array}{l}\text { Berbere } \\
\text { Aberegelle }\end{array}$ & $\begin{array}{l}\text { Tanqua } \\
\text { Abergelle }\end{array}$ & Tigray & 34 & $\begin{array}{l}\text { Acc- } \\
237528\end{array}$ & Enticho & Ahferom & Tigray \\
\hline 3 & Acc-3 & $\begin{array}{l}\text { Berebere } \\
\text { Birisheleko }\end{array}$ & Bure & Amhara & 35 & Acc-9102 & Achefer & $\begin{array}{l}\text { Mirab } \\
\text { Gojam }\end{array}$ & Amhara \\
\hline 4 & Acc-4 & Felege Da'ero & Mekelle & Tigray & 36 & Acc-9094 & Gooda & $\begin{array}{l}\text { Mirab } \\
\text { Gojam }\end{array}$ & Amhara \\
\hline 5 & Acc-5 & Berebere Agew & Ofla(Zata) & Tigray & 37 & Acc-9098 & Achefer & $\begin{array}{l}\text { Mirab } \\
\text { Gojam }\end{array}$ & Amhara \\
\hline
\end{tabular}




\begin{tabular}{|c|c|c|c|c|c|c|c|c|c|}
\hline 6 & Acc-6 & Berebere Dibdibo & Ahferom & Tigray & 38 & Acc-9104 & Merwi & $\begin{array}{l}\text { Mirab } \\
\text { Gojam }\end{array}$ & Amhara \\
\hline 7 & Acc-7 & $\begin{array}{l}\text { Shamba } \\
\text { berbereAdi }\end{array}$ & Welkait & Tigray & 39 & Acc-9099 & Amestya & $\begin{array}{l}\text { Mirab } \\
\text { Gojam }\end{array}$ & Amhara \\
\hline 8 & Acc-8 & Berebere korir & $\begin{array}{l}\text { Kilte } \\
\text { Awulalo }\end{array}$ & Tigray & 40 & Acc-9082 & Meacha & $\begin{array}{l}\text { Mirab } \\
\text { Gojam }\end{array}$ & Amhara \\
\hline 9 & Acc-9 & Berebere Tsalaiet & $\begin{array}{l}\text { Kola } \\
\text { Temben }\end{array}$ & Tigray & 41 & Acc-9101 & Achefer & $\begin{array}{l}\text { Mirab } \\
\text { Gojam }\end{array}$ & Amhara \\
\hline 10 & Acc-10 & Berebere Agbe & Abergelle & Tigray & 42 & Acc-9086 & Kudmie & $\begin{array}{l}\text { Mirab } \\
\text { Gojam }\end{array}$ & Amhara \\
\hline 11 & Acc-11 & Laelay Dayu & Alamata & Tigray & 43 & $\begin{array}{l}\text { Acc- } \\
229696\end{array}$ & Dibata & Metekel & B/Gumz \\
\hline 12 & Acc-12 & Berebere Hewane & Walkait & Tigray & 44 & Acc-9106 & $\begin{array}{l}\text { Bure } \\
\text { Wemberma }\end{array}$ & $\begin{array}{l}\text { Mirab } \\
\text { Gojam }\end{array}$ & Amhara \\
\hline 13 & Acc-13 & Abat Berebere & Walkait & Tigray & 45 & Acc-9007 & $\begin{array}{l}\text { Galioch Buare } \\
\text { town }\end{array}$ & $\begin{array}{l}\text { Mirab } \\
\text { Gojam }\end{array}$ & Amhara \\
\hline 14 & Acc-14 & Bora(Gemelo) & Embalaje & Tigray & 46 & Acc-9107 & Guzamn & $\begin{array}{l}\text { Misrak } \\
\text { Gojam }\end{array}$ & Amhara \\
\hline 15 & Acc-15 & Abat Berebere & Welkait & Tigray & 47 & Acc-28334 & Abdigudina & Illubabor & Oromiya \\
\hline 16 & Acc-16 & Berbere Rama & Mereb Leke & Tigray & 48 & Acc- 48 & Berbere Alaba & Alaba & SNNPRS \\
\hline 17 & Acc- 28336 & Durame & Illubabor & Oromiya & 49 & Acc-49 & Tedele & Guragae & SNNPRS \\
\hline 18 & $\begin{array}{l}\text { Acc- } \\
230800\end{array}$ & Bedeno & $\begin{array}{l}\text { Misrak } \\
\text { Harerge }\end{array}$ & Oromiya & 50 & $\begin{array}{l}\text { Acc- } \\
229694\end{array}$ & Mentawuha & Metekel & B/Gumz \\
\hline 19 & Acc- 28337 & Elammo & Illubabor & Oromiya & 51 & Acc-51 & Abeshigie & Guragie & SNNPRS \\
\hline 20 & $\begin{array}{l}\text { Acc- } \\
229699\end{array}$ & Adet & $\begin{array}{l}\text { Misrak } \\
\text { Gojam }\end{array}$ & Amhara & 52 & Acc-52 & Wegedadi & $\begin{array}{l}\text { Mirab } \\
\text { Gojam }\end{array}$ & Amhara \\
\hline 21 & $\begin{array}{l}\text { Acc- } \\
212912\end{array}$ & Kedida Gameala & $\begin{array}{l}\text { Kembata } \\
\text { Alaba }\end{array}$ & SNNPRS & 53 & Acc-9093 & Solmeda & $\begin{array}{l}\text { Mirab } \\
\text { Gojam }\end{array}$ & Amhara \\
\hline 22 & Acc-9097 & Achefer/Durbate & $\begin{array}{l}\text { Mirab } \\
\text { Gojam }\end{array}$ & Amhara & 54 & $\begin{array}{l}\text { Acc- } \\
229692\end{array}$ & Dinkara & Agew Awi & Amhara \\
\hline 23 & Acc-9084 & Merawi & $\begin{array}{l}\text { Mirab } \\
\text { Gojam }\end{array}$ & Amhara & 55 & Acc-55 & Debremarkos & $\begin{array}{l}\text { Misrak } \\
\text { Gojam }\end{array}$ & Amhara \\
\hline 24 & $\begin{array}{l}\text { Acc- } \\
229697\end{array}$ & Wonbera & Metekel & B/Gumz & 56 & Acc-56 & Finote Selam & $\begin{array}{l}\text { Mirab } \\
\text { Gojam }\end{array}$ & Amhara \\
\hline 25 & $\begin{array}{l}\text { Acc- } \\
212913\end{array}$ & Humbo & $\begin{array}{l}\text { Semen } \\
\text { Omo }\end{array}$ & SNNPRS & 57 & Acc-57 & $\begin{array}{l}\text { Guragie } \\
\text { Berebere }\end{array}$ & Butajira & SNNPRS \\
\hline 26 & $\begin{array}{l}\text { Acc- } \\
229700\end{array}$ & $\begin{array}{l}\text { Bibugn (Astero } \\
\text { M.) }\end{array}$ & $\begin{array}{l}\text { Misrak } \\
\text { Gojam }\end{array}$ & Amhara & 58 & Acc-58 & Berebere Merb & $\begin{array}{l}\text { Mereb } \\
\text { Leke }\end{array}$ & Tigray \\
\hline 27 & Acc- 9085 & Merawi & $\begin{array}{l}\text { Mirab } \\
\text { Gojam }\end{array}$ & Amhara & 59 & Acc-59 & Adiha Local & Abi Adi & Tigray \\
\hline 28 & $\begin{array}{l}\text { Acc- } \\
230798\end{array}$ & Dogo Midi Jara & $\begin{array}{l}\text { Misrake } \\
\text { Harerge }\end{array}$ & Oromiya & 60 & Acc- 23880 & $\begin{array}{l}\text { Meskele } \\
\text { Kirstos }\end{array}$ & $\begin{array}{l}\text { Semien } \\
\text { Gonder }\end{array}$ & Amhara \\
\hline 29 & $\begin{array}{l}\text { Acc- } \\
230799\end{array}$ & Girawa & $\begin{array}{l}\text { Misrake } \\
\text { Harerge }\end{array}$ & Oromiya & 61 & Acc-61 & Myweni & $\begin{array}{l}\text { Mereb } \\
\text { Leke }\end{array}$ & Tigray \\
\hline 30 & $\begin{array}{l}\text { Acc- } \\
236436\end{array}$ & Bako Tibe & $\begin{array}{l}\text { Mirab } \\
\text { Shewa }\end{array}$ & Oromiya & 62 & Acc- 62 & Berebere Hesea & $\begin{array}{l}\text { Mereb } \\
\text { Leke }\end{array}$ & Tigray \\
\hline 31 & $\begin{array}{l}\text { Acc- } \\
229698\end{array}$ & Dibate & Metekel & B/Gumz & 63 & Acc-63 & $\begin{array}{l}\text { Yeyeju } \\
\text { Bereberie }\end{array}$ & Woldia & Amhara \\
\hline 32 & $\begin{array}{l}\text { Acc- } \\
229698\end{array}$ & Dibate & Metekel & B/Gumz & 64 & Acc-64 & $\begin{array}{l}\text { Mareko fana } \\
\text { (St. check) }\end{array}$ & Melkassa & Oromiya \\
\hline
\end{tabular}

Data collected: Seventeen quantitative characters were recorded on five randomly selected plants from the two middle rows of each plot by adopting descriptors list for hot pepper (IPGRI, 1995).

Data Analysis: Data for quantitative characters were subjected to analysis of variances (ANOVA) for simple lattice design following procedures of SAS Version 9.2(SAS Institute Inc., 2010) to test the presence of significant differences among genotypes. Mean separations were estimated using Duncan Multiple Range Test (DMRT) at 5\% probability levels.

Variability among accessions was estimated using genotypic variances and coefficients of variations as suggested by Burton and De vane (1953) as: Genotypic Variance $\left(\sigma^{2} \mathrm{~g}\right)=\frac{\mathrm{MSg}-\mathrm{MSe}}{\mathrm{r}}$

Phenotypic variance $\left(\sigma^{2} \mathrm{p}\right)=\left[\sigma^{2} \mathrm{~g}+\left(\sigma^{2} \mathrm{e} / \mathrm{r}\right)\right]$, Phenotypic coefficient of variation $(\mathrm{PCV})=\frac{\sqrt{\sigma 2 p}}{\bar{x}} * 100$, Genotypic coefficient of variation $(\mathrm{GCV})=\frac{\sqrt{\sigma 2 g}}{\bar{x}} * 100$, Where, $\mathrm{r}=$ number of replication; MSg $=$ mean square due to 
genotypes and Mse = mean square of error, $\sigma^{2} \mathrm{p}=$ phenotypic variance, $\sigma^{2} \mathrm{~g}=$ genotypic variance and $\bar{x}=$ grand mean of the character under consideration. Both phenotypic coefficients of variation (PCV) and genotypic coefficients of variation (GCV) was categorized depending up on cut points suggested by Deshmukh et al. (1986) as low $(<10 \%)$, moderate $(10-20 \%)$ and high $(>20 \%)$.

Broad sense heritability (h2) of the all traits were calculated according to the formula as described by Allard (1960) as follow:

$$
\mathrm{h}^{2}{ }_{\mathrm{bs}}=\left[\left(\sigma^{2} \mathrm{G}\right) /\left(\sigma^{2} \mathrm{P}\right)\right] \times 100,
$$

Where: $\mathrm{h}^{2}{ }_{\mathrm{bs}}=$ heritability in broad sense; $\sigma^{2} \mathrm{G}=$ Genotypic variance; $\sigma^{2} \mathrm{P}=$ Phenotypic variance. According to Singh (2001) that heritability values $\geq 80 \%$ were very high, values from $60-79 \%$ were moderately high, values from 40 $59 \%$ were medium and values less than $40 \%$ were low.

Genetic Advance (GA) for selection intensity (K) at 5\%was computed according to Allard (1960) as given here:

$$
\mathrm{GA}=\mathrm{K}^{*} \sigma \mathrm{p}^{*} \mathrm{H}^{2}
$$

Where, $\mathrm{GA}=$ expected genetic advance, $\mathrm{K}=$ the standardized selection differential at $5 \%$ selection intensity $(\mathrm{K}=$ 2.063), $\sigma \mathrm{p}=$ is phenotypic standard deviation on mean basis and $\mathrm{H}^{2}=$ heritability in the broad sense. The genetic advance as percentage of population means (GAM) was also estimated with the methods described by Johnson et al. (1955). Genetic advance as \% of mean (GAM) was computed as: $\quad$ GAM $=\frac{G A}{\bar{x}} * 100$

Where, $\mathrm{GA}=$ Genetic advance under selection and $\bar{x}=$ mean of the population. According to Johson et al. (1955) genetic advance as percent of mean was classified as low $(<10 \%)$, moderate $(10-20 \%)$ and high $(>20 \%)$.

Characters associations at genotypic and phenotypic levels were calculated from the genotypic and phenotypic and environmental covariance according to Singh and Chaundhary (1985). In Path analysis, total yield per hectare was taken as the resultant (dependent) variable while the rest of the characters were considered as casual (independent) variables. The direct and indirect effects of the independent characters on fruit yield per hectare were estimated by the simultaneous solution of the formula suggested by Dewey and Lu (1959).

\section{Results and Discussion}

\section{Analysis of Variance (ANOVA)}

There were highly significant differences $(\mathrm{P}<0.01)$ among the tested genotypes for all characters studied indicating presence of adequate variability among genotypes (Table 2). This significant genetic variation among genotypes suggested that the genotypes were genetically diverse and it could be a good opportunity for breeders to select genotypes for trait of interest for variety development. This finding was in agreement with the findings of Berhanu et al. (2011), Nsabiyera et al. (2013), Birhanu (2017) and Shimeles (2018).

Mean Performance of Genotypes: Genotypes had 57.5 to 76.5 days to flowering, 67.5 to 84.5 days to fruiting and 113.5 to133 days to maturity with a mean of $62.27,75.78$ and 122.6 days, respectively. The result showed a wide range of variations for days to flowering, fruiting and maturity. Similarly, Shimeles (2018) and Berhanu et al. (2011) reported the existence of wide genetic variation for those phenological characters on 49 and 20 hot pepper genotypes respectively. Acc-1 (113.5 days), Acc-49 (114.5 days) and Acc-57 (114 days) had significantly shorter days to maturity while Acc-5 (133 days), Acc-9 (130.5days) and Acc-59 (130.5days) had significantly delayed maturity. About $54.7 \%$ of the genotypes exhibited shorter number of days to maturity than the genotypes mean (122.6). Moreover, 25 genotypes were significantly earlier in maturity than the check variety (Mareko fana) that had the earliest days to maturity (Appendix Table 1). Most of the genotypes have also yield advantage over the early maturing check variety. Hence, there is an opportunity to select early maturing and high yielder genotypes better than the check variety (Mareko fana).

The magnitude of genetic variability for plant height ranged from 37.1 (Acc-9097) to $66.5 \mathrm{~cm}$ (Acc-3) with average value of $53.29 \mathrm{~cm}$. Genotypes codded as Acc-63, Acc-9007, Acc-8, Acc-212912, Acc-1, Acc-9, Acc-59, Acc-5 and Acc-9102 had tall plant stature $(59.4-65 \mathrm{~cm})$, so can be used as parents in developing varieties with maximum plant height, as it may contribute to fruit yield.

The minimum and maximum canopy diameter was exhibited by genotypes Acc-229697 and Acc-59, respectively. Genotypes Acc-59, Acc-15 and Acc-9101 have also yield advantage and can be used as parents in developing varieties with high canopy diameter over the check variety. However, Shimeles (2018) reported a wide range of $40.9-76.6 \mathrm{~cm}$ for canopy diameter. This wide range of variability may be attributed to differences in the materials test and /or may be due to the differences of in the testing environments.

The fruit pericarp thickness of genotypes also ranged from 1.7 to $2.7 \mathrm{~mm}$ with an overall mean of $2.1 \mathrm{~mm}$. The genotypes Acc-212912, Acc-212913, Acc-230798, Acc-236436, Acc-229698, Acc-16, Acc-11, Acc-48, and Acc- 
51 had thicker pericarp than the check variety. The highest fruit pericarp thickness was Acc-212912 (2.7 mm) which indicated that Acc-212912 should be given consideration for selection designed for the improvement of this trait. This is in agreement with the finding of Nsabiyera et al. (2013) and Shimeles (2018) who reported a wide range of variation for fruit pedicel length, fruit length and fruit diameter. Average single fruit weight varied from 1.55 to $7.1 \mathrm{gm}$ with a mean of $3.6 \mathrm{~g}$. Acc-49, Acc-212912, Acc-61, Acc-1, Acc-11, Acc-212913 and Acc-229694 depicted highest fruit weight per plant comparing to the check variety in that order.

The genotypes exhibited significant variability in fruit number per plant which ranged from 14.75 to 55.5 with a mean of 31. The lowest number of fruits per plant was depicted by genotypes Acc-57, Acc-56, Acc-229698 and Acc-49, whereas the highest number of fruits per plant by genotypes Acc-5, Acc-2, Acc-59, Acc-229700, Acc212913, Acc-8 and Acc-229697. On the other hand, number of seeds per fruit ranged between 93 and 231 with a mean value of 139.1. The lowest number of seeds per fruit was counted for Acc-229697 and Acc-14, whereas the highest seeds per fruit for Acc-212912, Acc-3, Acc-48 and Acc-4 respectively. Accordingly, in the current study 42 genotypes scored greater than $65 \%$ number of fruits per plant and 33 genotypes scored greater than $51 \%$ number of seeds per fruit as compared with the best performing check variety (Mareko fana) (Table 5). Similar results for number fruits per plant were reported by kadwey et al. (2015), Birhanu (2017), Kumari (2017) and Shimeles (2018).

A wide range of variation was observed for 1000 seed weight among genotypes which ranged from 4 to $7.2 \mathrm{~g}$ with a mean of 5.6g. Genotypes Acc-212913, Acc-58, Acc-229694, Acc-212912 and Acc-11 had high seed weight of 7.2, 6.9, 6.9, 6.8 and $6.6 \mathrm{~g}$ while Acc-9085, Acc-9101, Acc-9099 and Acc-9086 had low 1000 seed weight of 4g each as compared to the check variety.

Average dry fruit yield per plant ranged from 54 to $172.5 \mathrm{~g}$ with an overall mean of $107.3 \mathrm{~g}$. The highest yield per plant was recorded from Acc-212913 (172.5g) and Acc-4 (168g) while Acc-13 (54.5 g), Acc-237528 (56 g) and Acc-9102 (64 g) produced lowest yield per plant as compared to the check variety. Similar results for dry fruit yield per plant were reported by kadwey et al. (2015), Rosmaina et al. (2016) and Shimeles (2018).

Table 2. Mean squares of variance for 19 characters of 64 hot pepper genotypes evaluated at Mereb Lekhe in, $2017 / 18$

\begin{tabular}{|c|c|c|c|c|c|c|c|c|}
\hline \multicolumn{9}{|c|}{ Mean squares } \\
\hline \multirow{4}{*}{ Characters } & & \multicolumn{7}{|c|}{ Error } \\
\hline & \multirow{3}{*}{ Replication(1) } & \multirow{3}{*}{$\begin{array}{l}\text { Treatments } \\
\text { Adji (63) }\end{array}$} & \multirow{3}{*}{$\begin{array}{l}\text { Blocks } \\
\text { with } \\
\text { in } \\
\text { replication } \\
(\text { Adj)(14) }\end{array}$} & \multirow{3}{*}{ Block(49) } & \multirow[t]{3}{*}{$\operatorname{RCBD}(63)$} & \multirow{3}{*}{$\mathrm{R}^{2}(\%)$} & \multirow{3}{*}{$\begin{array}{l}\text { RE to } \\
\text { RCBD } \\
(\%)\end{array}$} & \multirow{3}{*}{$\begin{array}{l}\text { CV } \\
(\%)\end{array}$} \\
\hline & & & & & & & & \\
\hline & & & & & & & & \\
\hline DFL & 8.508 & $27.51^{* *}$ & 13.936 & 6.528 & 8.175 & 86.9 & 112.1 & 3.8 \\
\hline DFR & 0.008 & $30.17^{* *}$ & 8.820 & 6.347 & 6.897 & 87.2 & 102.3 & 3.3 \\
\hline DM & 3.445 & $44.26^{* *}$ & 6.222 & 5.856 & 5.937 & 91.2 & 100.1 & 2.0 \\
\hline PH & 526.500 & $62.76^{* *}$ & 15.390 & 17.487 & 17.021 & 84.7 & 97.3 & 7.8 \\
\hline $\mathrm{CD}$ & 7.703 & $14.69^{* *}$ & 3.318 & 3.550 & 3.499 & 86.9 & 98.6 & 5.0 \\
\hline NPB & 0.797 & $13.45^{* *}$ & 1.100 & 1.117 & 1.113 & 94.6 & 99.7 & 15.0 \\
\hline SD & 1.144 & $3.37^{* *}$ & 1.241 & 0.963 & 1.025 & 84.0 & 101.4 & 7.7 \\
\hline FPL & 0.054 & $0.79^{* *}$ & 0.119 & 0.074 & 0.084 & 94.3 & 104.7 & 7.8 \\
\hline FL & 0.002 & $22.28^{* *}$ & 0.426 & 0.407 & 0.411 & 98.7 & 100.0 & 7.8 \\
\hline FD & 1.533 & $49.14^{* *}$ & 2.355 & 1.638 & 1.797 & 97.7 & 102.8 & 7.1 \\
\hline FPT & 0.918 & $0.13^{* *}$ & 0.026 & 0.029 & 0.028 & 87.9 & 97.3 & 8.3 \\
\hline FW & 0.463 & $4.82^{* *}$ & 0.144 & 0.187 & 0.177 & 97.3 & 95.0 & 11.9 \\
\hline NFP & 2.820 & $294.20^{* *}$ & 8.135 & 4.555 & 5.351 & 98.9 & 107.0 & 6.9 \\
\hline NSF & 17.331 & $1453.86^{* *}$ & 80.555 & 18.524 & 32.309 & 99.1 & 148.9 & 3.1 \\
\hline TSW & 0.538 & $1.50^{* *}$ & 0.213 & 0.189 & 0.194 & 91.8 & 100.3 & 7.8 \\
\hline DFYP & 12.500 & $1741.51^{* *}$ & 37.670 & 20.676 & 24.452 & 99.2 & 107.5 & 4.2 \\
\hline MFY & 1.304 & $0.81^{* *}$ & 0.069 & 0.131 & 0.117 & 90.5 & 89.6 & 14.6 \\
\hline UNMFY & 0.008 & $0.01^{* *}$ & 0.001 & 0.001 & 0.001 & 92.1 & 91.4 & 19.7 \\
\hline TFY & 1.533 & $0.82^{* *}$ & 0.065 & 0.135 & 0.120 & 90.5 & 88.5 & 13.8 \\
\hline
\end{tabular}

*and $* *=$ significant at $5 \%$ and $1 \%$ probability level, respectively. Number in parenthesis represented degree of freedom adj $=$ adjusted treatment mean squares, $\mathrm{RCBD}=$ Randomized completed block design, $\mathrm{RE}$ to $\mathrm{RCBD}=$ 
Relative efficiency to randomized completed block design $\mathrm{CV}=$ coefficient of variation, $\mathrm{R}^{2}(\%)=$ coefficient of determination, $\mathrm{DFL}=$ days to $50 \%$ flowering, $\mathrm{DFR}=$ days to $50 \%$ fruiting, $\mathrm{DM}=$ days to maturity, $\mathrm{PH}=\mathrm{Plant}$ height $(\mathrm{cm}), \mathrm{CD}=$ canopy diameter $(\mathrm{cm})$, number of primary branches per plant, $\mathrm{SD}=$ stem diameter $(\mathrm{mm}), \mathrm{FPL}$ $=$ fruit pedicel length $(\mathrm{cm}), \mathrm{FL}=$ fruit length $(\mathrm{cm}), \mathrm{FD}=$ fruit diameter $(\mathrm{mm}), \mathrm{FPT}=$ fruit pericarp thickness $(\mathrm{mm})$, $\mathrm{FW}=$ average single fruit weight $(\mathrm{g}), \mathrm{NFP}=$ number of fruits per plant, NSF $=$ number of seeds per fruit, TSW $=$ thousand seed weight $(\mathrm{g})$, DFYP $=$ dry fruit yield per plant $(\mathrm{g})$, MFY $=$ marketable fruit yield $\left(\mathrm{t} \mathrm{ha}^{-1}\right), \mathrm{UNMFY}=$ Unmarketable fruit yield $\left(\mathrm{t} \mathrm{ha}^{-1}\right)$ and TFY $=$ total fruit yield $\left(\mathrm{t} \mathrm{ha}^{-1}\right)$.

Marketable fruit yield per hectare ranged from 0.7- $4.3 \mathrm{t}$ with an overall mean of $2.5 \mathrm{t} \mathrm{ha}^{-1}$. The highest marketable fruit yield per hectare was recorded for Acc-4, Acc-212913, Acc-212912, Acc-1, Acc-49, and Acc-50 while Acc9102, Acc-52, Acc-9099, Acc-9098, Acc-230798 and Acc-230799 gave the lowest yield as compared to the check variety (Appendix Table 2). Hence, there is an opportunity to select high yielding genotypes better than the check variety. Total fruit yield per hectare ranged from 0.83 to $4.6 \mathrm{t} \mathrm{ha}^{-1}$ which showed wide variation with a mean value of $2.7 \mathrm{t}$ ha-1. The maximum yield was obtained from Acc-4 (4.6 $\left.\mathrm{t} \mathrm{ha}^{-1}\right)$ followed by Acc-212912 (4.5 $\left.\mathrm{t} \mathrm{ha}^{-1}\right)$, Acc$212913\left(4.3 \mathrm{t} \mathrm{ha}^{-1}\right)$ and Acc-3 (4.3 t ha $\left.\mathrm{f}^{-1}\right)$ (Appendix Table 2). Nearly, $43.8 \%$ of the tested genotypes had fruit yields above the grand mean of genotypes. As compared with the best performing check variety (Mareko fana), $54.6 \%$ of the genotypes had yield advantages. Most of these high yielding genotypes were also earlier in maturity than the check variety (Appendix Table 2). This wide range of variability of genotypes for most traits in the study indicated the high possibility for genetic improvement of traits under consideration.

Phenotypic and Genotypic Variations: For all characters studied, the magnitude of environmental variance was lower than the corresponding genotypic variance (Table 3). This indicates that the genotypic component of variation was the major contributor to the total variation in the studied characters. Genetic variance ranged from 0.05 for fruit pericarp thickness to 860.42 for dry fruit yield per plant while phenotypic variance values ranged from 0.07 to 870.76 for fruit pericarp thickness. The GCV ranged from $3.6 \%$ for days to maturity to $42 \%$ for average fruit weight. Similarly, PCV ranges from $3.8 \%$ for days to maturity to $42.9 \%$ for average fruit weight per plant. In general, the phenotypic coefficient of variation (PCV) was relatively higher than the corresponding genotypic coefficient of variation (GCV). The difference between PCV and GCV was narrow indicating little influence of environment on the expression of these characters and considerable amount of variation was observed for all the characters. The GCV and PCV values are normally categorized as low $(<10 \%)$, moderate $(10-20 \%)$ and high ( $>20 \%)$ as indicated by Deshmukh et al. (1986). High values of PCV and GCV indicated the existence of substantial variability for such characters and selection may be effective based on these characters.

Average fruit weight had the highest GCV and PCV (42and 42.9\%) followed by fruit length (40.3 and 40.7\%), number of fruits per plant (38.9 and 39.2\%), number of primary branches per plant (35.2\% and $36.7 \%$ ), dry fruit yield per plant (27.3 and 38.9\%), fruit diameter (24.6 and 27.5\%), total fruit yield (22 and $24.1 \%$ ), number of fruits per plant (38.9 and 39.2\%). Medium GCV and high PCV were observed for fruit pericarp thickness (11 and 12.4\%), fruit pedicel length (17.2 and 18.1\%), number of seeds per fruit (19.3 and 19.4\%) and thousand seed weight (14.5 and $15.6 \%$ ). GCV and PCV were low for days to $50 \%$ flowering (7.3 and 7.8), days to $50 \%$ fruiting (6.9 and $7.3 \%$ ) and days to maturity (5.2 and 5.4\%), plant height (8.9 and 10.5\%) and canopy diameter (6.3 and 7.2\%). Similarly, Pujar et al. (2017) reported a relatively low GCV and PCV for days to flowering in 63 chilli genotypes. The high PCV and GCV are evident for the high variability that in turn offers good scope for selection.

Similar finding was reported by Berhanu et al. (2011) indicating that days to flowering and days to maturity had low GCV and PCV values, while fruit weight, number fruits per plant, number of primary branches per plant had high GCV and PCV. Datta and Das (2013) reported high GCV and PCV with high heritability and GAM for fruit number per plant and fruit yield per plant. Razzaq et al. (2016) reported high values of GCV and PCV for weight of red fruit (110 and 112\%) and number of fruits per plant (85 and 86\%). Shimeles et al. (2016) also reported high estimates of GCV and PCV for fruit weight, number of branches per plant and number of fruits per plant. In addition, similar findings were also reported by (Sharma et al., 2010; Janaki et al., 2015; Rosmaina et al., 2016; Sahu et al., 2016).

Estimates of Heritability $\left(\mathbf{h}^{2}\right)$ in broad Sense: In this study all the traits had moderate high to very high broad sense heritability in the range of 71.4 to $98.8 \%$ (Table 3) indicating that the traits studied were more influenced by genetic factors (Rosmaina et al., 2016). According to Singh (2001) heritability values greater than $80 \%$ considered as a very high, values from $60-79 \%$ as moderately high, values from $40-59 \%$ as medium and values less than $40 \%$ as low. Accordingly, the estimates of heritability of all traits in the current study were moderate to very high. The characters having very high heritability indicated relatively small contribution of the environmental factors to the phenotype and selection for such characters could be fairly easy due to high additive effect. 
Heritability alone provides no indication of the amount of genetic improvement that would result from selection of individual genotype. Hence, knowledge on heritability coupled with genetic advance is more useful. Genetic advance as percent of the mean (GAM) in this study ranged from $6.9 \%$ to $85 \%$ for days to maturity and average single fruit weight respectively (Table 6). According to Jonhson et al. (1955) the value of GAM is categorized as low $(<10 \%)$, moderate $(10-20 \%)$ and high $(>20 \%)$. The highest GAM was recorded for average single fruit weight $(85 \%)$, followed by fruit length $(82.4 \%)$, number of fruits per plant $(79.5 \%)$ and number of primary branches per plant (69.5\%) indicating that these characters are governed by additive genes and selection will be rewarding for improvement of hot pepper for these traits. The least GAM was recorded for days to maturity (6.9 \%), days to $50 \%$ fruiting (8.4\%) and days to 50\% flowering (8.7\%). In the current result, moderately high heritability coupled with moderate GAM was observed for plant height $(15.6 \%)$, canopy diameter $(11.3 \%)$, stem diameter $(15.1 \%)$ and fruit pericarp thickness $(19.9 \%)$. These results agreed with the findings of earlier researchers (Janaki et al., 2015; Rosmaina et al., 2016; Birhanu, 2017; Kumari, 2017) who found high genetic advance as percent of mean for number of fruits per plant, average fruit weight, and number of primary branches per plant. Shimeles et al. (2016) also obtained high genetic advance as percent of mean for number of branches per plant. Similar findings were reported by earlier workers for some characters with moderate to high GCV, PCV, heritability and GAM estimates, for fruit yield per plant, fruit diameter, fruit length, average fruit weight, number of seeds per fruit and number of fruits per plant (Sharma et al., 2010; Sahu et al., 2016; Razzaq et al., 2016; Pujar et al., 2017).

Generally, for characters like dry fruits yield per plant, number of fruits per plant, number of seeds per fruit, average single fruit weight, fruit diameter, fruit length and thousand seed weight with high GCV, heritability and GAM should be considered as reliable selection criteria for crop improvement in terms of yield and its components in hot pepper.

Association of Characters: In most cases, the genotypic correlation coefficients were higher than the phenotypic correlation coefficient which indicates that the inherent association among various characters independent of environmental influence (Table 4). Total fruit yield per hectare showed positive and highly significant $(\mathrm{P}<0.01)$ genotypic and phenotypic correlations with dry fruit yield per plant $\left(r_{g}=0.75\right.$ and $\left.r_{p}=0.70\right)$, average single fruits weight $\left(r_{g}=0.52\right.$ and $\left.r_{p}=0.49\right)$, thousand seed weight $\left(r_{g}=0.47\right.$ and $\left.r_{p}=0.41\right)$, fruit pericarp thickness $\left(r_{g}=0.44\right.$ and $\left.r_{p}=0.42\right)$, number of seeds per fruit $\left(r_{g}=0.42\right.$ and $\left.r_{p}=0.39\right)$ and fruit diameter $\left(r_{g}=0.37\right.$ and $\left.r_{p}=0.33\right)$. Total fruit yield also exhibited positive and significant $(\mathrm{P}<0.05)$ genotypic and phenotypic correlations with canopy diameter, stem diameter and fruit length (Table 4). The results imply that improvement of the characters could improve capacity to synthesize and translocate photosynthesis to the organ of economic value.

This suggested that, improvement of those characters would result in a substantial increment on fruit yield that could be used in selection of genotypes for high fruit yield. Similarly, Abrham et al. (2017) and Shimeles (2018) reported higher genotypic correlation coefficients than the phenotypic ones, implying the inherent associations between various characters in Ethiopian Capsicums.

Dry fruit yield per plant had a highly significant association at both genotypic and phenotypic level with average single fruit weight $\left(r_{g}=0.50, r_{p}=0.56\right)$, number of seeds per fruit $\left(r_{g}=0.46, r_{p}=0.45\right)$ and thousand seed weight $\left(r_{\mathrm{g}}=0.43, \mathrm{r}_{\mathrm{p}}=0.40\right)$. These results agreed with the findings of earlier researchers (Kadwey et al., 2015; Chakrabarty and Aminul , 2017; Kumari et.al, 2017) indicating genotypic and phenotypic correlations between plant height, number of primary branches per plant, fruit length, fruit diameter, fruit pericarp thickness, fruit yield per plant, average fruit weight, number of fruit per plant, number of seeds per fruit and thousand seed weight.

Table 3. Estimates of Range, Mean, Genotypic, Environmental and Phenotypic variances and Coefficient of variations, Heritability in broad sense, Genetic advance and Genetic advance as percentage of mean for 17 characters of 64 hot Pepper genotypes at Mereb Lekhe in, 2017/18

\begin{tabular}{lcccccccccc}
\hline Characters & Ranges & Mean \pm SEM & $\sigma^{2} \mathrm{~g}$ & $\sigma^{2} \mathrm{e}$ & $\sigma^{2} \mathrm{p}$ & $\mathrm{GCV}(\%)$ & $\mathrm{PCV}(\%)$ & $\mathrm{h}^{2}(\%)$ & GA & GAM $(\%)$ \\
\hline DFL & $57.5-75.9$ & $67.3 \pm 1.8$ & 10.5 & 6.53 & 13.76 & 4.8 & 5.5 & 76.3 & 5.84 & 8.7 \\
DFR & $67.5-84.5$ & $75.7 \pm 1.8$ & 11.9 & 6.35 & 15.09 & 4.6 & 5.1 & 79.1 & 6.33 & 8.4 \\
DM & $113.5-133$ & $122.6 \pm 1.7$ & 19.2 & 5.86 & 22.13 & 3.6 & 3.8 & 86.8 & 8.42 & 6.9 \\
PH & $37.1-66.5$ & $53.3 \pm 3$ & 22.6 & 17.49 & 31.38 & 8.9 & 10.5 & 72.1 & 8.34 & 15.6 \\
CD & $32.4-43.4$ & $37.4 \pm 1.3$ & 5.6 & 3.55 & 7.34 & 6.3 & 7.3 & 75.8 & 4.24 & 11.3 \\
NPB & $3.4-11.8$ & $7.1 \pm 0.8$ & 6.2 & 1.12 & 6.72 & 35.2 & 36.7 & 91.7 & 4.9 & 69.5 \\
SD & $9.8-16.1$ & $12.7 \pm 0.7$ & 1.2 & 0.96 & 1.68 & 8.6 & 10.2 & 71.4 & 1.91 & 15.1 \\
FPL & $2.3-4.7$ & $3.5 \pm 0.2$ & 0.4 & 0.07 & 0.39 & 17.2 & 18.1 & 90.6 & 1.17 & 33.9 \\
FL & $4-2.8$ & $8.2 \pm 0.5$ & 10.9 & 0.40 & 11.14 & 40.3 & 40.7 & 98.2 & 6.76 & 82.4 \\
\hline
\end{tabular}




\begin{tabular}{lcccccccccc}
\hline FD & $11.21-31$ & $18 \pm 0.9$ & 23.7 & 1.64 & 24.57 & 27.0 & 27.5 & 96.7 & 9.89 & 54.8 \\
FPT & $1.7-2.7$ & $2.1 \pm 0.1$ & 0.1 & 0.03 & 0.07 & 10.9 & 12.4 & 77.7 & 0.41 & 19.9 \\
DFYP & $53.96-173.6$ & $107.3 \pm 3.2$ & 860.4 & 20.68 & 870.76 & 27.3 & 27.5 & 98.8 & 60.15 & 56.0 \\
FW & $1.55-7.1$ & $3.6 \pm 0.3$ & 2.3 & 0.19 & 2.41 & 42.0 & 42.9 & 96.1 & 3.08 & 85.0 \\
NFP & $14.3-55.7$ & $30.9 \pm 1.5$ & 144.8 & 4.56 & 147.1 & 38.9 & 39.7 & 98.5 & 24.63 & 79.5 \\
NSF & $90.66-233.6$ & $139.1 \pm 3.1$ & 717.7 & 18.52 & 726.93 & 19.7 & 19.4 & 98.7 & 54.91 & 39.5 \\
TSW & $4-7.2$ & $5.56 \pm 0.3$ & 0.7 & 0.19 & 0.75 & 14.5 & 15.6 & 87.4 & 1.56 & 28.1 \\
TFY & $0.8-4.5$ & $2.7 \pm 0.3$ & 0.3 & 0.14 & 0.41 & 22.1 & 24.1 & 83.6 & 1.11 & 41.5 \\
\hline
\end{tabular}

$\mathrm{DFL}=$ days to $50 \%$ flowering, $\mathrm{DFR}=$ days to $50 \%$ fruiting, $\mathrm{DM}=$ days to maturity, $\mathrm{PH}=$ plant height, $\mathrm{CD}=$ canopy diameter, $\mathrm{NPB}=$ number of primary branches per plant, $\mathrm{SD}=$ stem diameter, $\mathrm{FPL}=$ fruit pedicel length , $\mathrm{FL}=$ fruit length, $\mathrm{FD}=$ fruit diameter, $\mathrm{FPT}=$ fruit pericarp thickness, $\mathrm{DFYP}=$ dry red fruit yield per plant, $\mathrm{FW}=$ average fruit weight, NFP = number of fruits per plant, NSF = number of seeds per fruit, TSW $=$ thousand seed weight and TFY = total fruit yield, $\mathrm{SEM}=$ standard error of the mean, $\sigma^{2} \mathrm{~g}=$ genotypic variance, $\sigma^{2} \mathrm{e}=$ error variance, $\sigma^{2} p=$ phenotypic variance, $\mathrm{PCV}=$ phenotypic coefficient of variance, $\mathrm{GCV}=$ genotypic coefficient of variance, $\mathrm{h}^{2}=$ broad sense heritability, $\mathrm{GA}=$ genetic advance, GAM = genetic advance as percent of mean.

Genotypic path coefficient analysis: In this study, the result of genotypic path coefficient analysis showed that dry red fruit yield per plant (0.46) had the highest positive direct effect on total fruit yield per hectare followed by fruit pericarp thickness $(0.37)$, number of primary branches per plant $(0.31)$, canopy diameter $(0.2)$, thousand seed weight $(0.18)$, average single fruit weight $(0.16)$, fruit pedicel length and stem diameter $(0.11)$, while negative direct effect was observed for days to maturity (-0.21), fruit length $(-0.2)$, fruit diameter $(-0.15)$ and days to $50 \%$ flowering (- 0.08) while, days to 50\% fruiting, plant height and number of seeds per fruit had very little positive direct effect on fruit yield per hectare though it exhibited significant and positive association with fruit yield (Table 5). This indicates the true relationship between these characters as a good contributor to fruit yield.

Similarly, Shimeles (2018) reported that direct influence of pericarp thickness on fruit yield was very high and positive and its indirect influence through fruit diameter was also positive. However, pericarp thickness showed high negative indirect effect on number of fruits per plant. Generally, based on the genotypic path analysis of agronomic characters which showed positive direct effects on fruit yield per hectare were: dry fruit yield per plant, fruit pericarp thickness, average single fruit weight, number of primary branches per plant, canopy diameter and number of seeds per fruit. This result agrees with that of Kumari (2017).

In conclusion, the present study confirmed the existence of enormous genetic variability among the hot pepper germplasm for various important morphological traits. Hence there is an opportunity to exploit these traits in order to develop genotypes that perform better than the existing varieties for the future pepper improvement program.

Table 4. Estimates of genotypic (above diagonal) and phenotypic (below diagonal) correlation coefficient for 17 characters of 64 Hot pepper genotypes tested under irrigation in northern Ethiopia

\begin{tabular}{|c|c|c|c|c|c|c|c|c|c|c|c|c|c|c|c|c|c|}
\hline Traits & DFL & DFR & DM & PH & $\mathrm{CD}$ & NPB & SD & FPL & $\mathrm{FL}$ & FD & FPT & DFYP & FW & NFP & NSF & TSW & TFY \\
\hline & & & & $0.48^{*}$ & & & & & & & & - & & & & - & - \\
\hline \multirow[t]{2}{*}{ DFL } & 1.00 & $0.79 * *$ & $0.58^{* *}$ & * & $0.26^{*}$ & $0.40^{*}$ & $0.49^{* *}$ & $-0.25^{*}$ & $-0.30^{*}$ & $-0.26^{*}$ & $-0.31^{*}$ & $0.12 \mathrm{~ns}$ & $-0.29 *$ & $0.31^{*}$ & $-0.11 \mathrm{~ns}$ & $0.22 \mathrm{~ns}$ & $0.08 \mathrm{~ns}$ \\
\hline & & & & $0.41^{*}$ & & & & & - & - & - & - & - & & - & - & - \\
\hline DFR & $0.72^{* *}$ & 1.00 & $0.72^{* *}$ & $*$ & $0.22 \mathrm{~ns}$ & $0.54 * *$ & $0.47^{* * *}$ & $-0.34^{*}$ & $0.45^{* *}$ & $0.44 * *$ & $0.44 * *$ & $0.18 \mathrm{~ns}$ & $0.46 * *$ & $0.43^{* *}$ & $0.24 \mathrm{~ns}$ & $0.33^{* *}$ & $0.13 \mathrm{~ns}$ \\
\hline & & & & & & & & & - & - & - & & - & & - & - & \\
\hline DM & $0.54 * *$ & $0.62^{* *}$ & 1.00 & $0.29^{*}$ & $0.32^{* *}$ & $0.66^{* *}$ & $0.39 * *$ & $0.45^{* *}$ & $0.69^{* *}$ & $0.60^{* *}$ & $0.60^{* *}$ & $0.33^{* *}$ & $0.65 * *$ & $0.55^{* *}$ & $0.33^{* *}$ & $0.47 * *$ & $-0.28^{*}$ \\
\hline \multirow[t]{2}{*}{$\mathrm{PH}$} & $0.37^{* *}$ & $0.31^{* *}$ & $0.26^{* *}$ & 1.00 & $0.18 \mathrm{~ns}$ & $0.11 \mathrm{~ns}$ & $0.73^{* *}$ & $0.07 \mathrm{~ns}$ & $0.04 \mathrm{~ns}$ & $0.03 \mathrm{~ns}$ & $0.00 \mathrm{~ns}$ & $0.06 \mathrm{~ns}$ & $0.09 \mathrm{~ns}$ & $0.13 \mathrm{~ns}$ & $0.14 \mathrm{~ns}$ & $0.09 \mathrm{~ns}$ & $0.20 \mathrm{~ns}$ \\
\hline & & & & & & & & - & & - & - & & - & & - & - & \\
\hline \multirow[t]{2}{*}{$\mathrm{CD}$} & $0.25 * *$ & $0.18^{* *}$ & $0.31^{* *}$ & $0.20^{*}$ & 1.00 & $0.39 * *$ & $0.41^{* *}$ & $0.23 \mathrm{~ns}$ & $-0.27^{*}$ & $0.24 \mathrm{~ns}$ & $0.23 \mathrm{~ns}$ & $0.07 \mathrm{~ns}$ & $0.16 \mathrm{~ns}$ & $0.35^{* *}$ & $0.04 \mathrm{~ns}$ & $0.01 \mathrm{~ns}$ & $0.28^{*}$ \\
\hline & & & & $0.12 \mathrm{n}$ & & & & - & - & - & - & & - & & & - & - \\
\hline \multirow[t]{2}{*}{ NPB } & $0.34 * *$ & $0.47 * *$ & $0.61^{* *}$ & $\mathrm{~s}$ & $0.37 * *$ & 1.00 & $0.31 *$ & $0.58^{* *}$ & $0.73 * *$ & $0.62 * *$ & $0.60^{* *}$ & $-0.11 \mathrm{~ns}$ & $0.63 * *$ & $0.70 * *$ & $-0.26^{*}$ & $0.48^{* *}$ & $0.02 \mathrm{~ns}$ \\
\hline & & & & $0.61^{*}$ & & & & - & - & & - & & - & & & & \\
\hline \multirow[t]{2}{*}{ SD } & $0.38^{* *}$ & $0.37 * *$ & $0.31^{* *}$ & * & $0.36^{* *}$ & $0.27^{* *}$ & 1.00 & $0.08 \mathrm{~ns}$ & $0.06 \mathrm{~ns}$ & $-0.11 \mathrm{~ns}$ & $0.16 \mathrm{~ns}$ & $0.10 \mathrm{~ns}$ & $0.07 \mathrm{~ns}$ & $0.38^{* *}$ & $0.07 \mathrm{~ns}$ & $0.09 \mathrm{~ns}$ & $0.26^{*}$ \\
\hline & - & - & - & $0.06 \mathrm{n}$ & & - & - & & & & & & & - & & & \\
\hline \multirow[t]{2}{*}{ FPL } & $0.24 * *$ & $0.32^{* *}$ & $0.39 * *$ & $\mathrm{~s}$ & $-0.19 *$ & $0.52 * *$ & $0.09 \mathrm{~ns}$ & 1.00 & $0.59^{* *}$ & $0.60^{* *}$ & $0.52 * *$ & $0.15 \mathrm{~ns}$ & $0.51^{* *}$ & $0.51 * *$ & $0.35^{* *}$ & $0.26^{*}$ & $0.19 \mathrm{~ns}$ \\
\hline & - & - & - & $0.03 \mathrm{n}$ & - & & - & & & & & & & - & & & \\
\hline \multirow[t]{2}{*}{$\mathrm{FL}$} & $0.27 * *$ & $0.41^{* *}$ & $0.64 * *$ & $\mathrm{~s}$ & $0.25^{* *}$ & $0.69^{* *}$ & $0.05 \mathrm{~ns}$ & $0.56^{* *}$ & 1.00 & $0.72^{* *}$ & $0.67 * *$ & $0.27^{*}$ & $0.80^{* *}$ & $0.66^{* *}$ & $0.30^{*}$ & $0.62^{* *}$ & $0.25^{*}$ \\
\hline & - & - & - & $0.02 \mathrm{n}$ & & - & - & & & & & & & - & & & \\
\hline \multirow[t]{2}{*}{ FD } & $0.24 * *$ & $0.40^{* *}$ & $0.56^{* *}$ & $\mathrm{~s}$ & $-0.22^{*}$ & $0.59 *$ & $0.09 \mathrm{~ns}$ & $0.57 * *$ & $0.70^{* *}$ & 1.00 & $0.84 * *$ & $0.37^{* *}$ & $0.79 * *$ & $0.70^{* *}$ & $0.60^{* *}$ & $0.47^{* *}$ & $0.37^{* *}$ \\
\hline & - & - & - & & & - & - & & & & & & & - & & & \\
\hline FPT & $0.26 * *$ & $0.36^{* *}$ & $0.50^{* *}$ & $0.11 \mathrm{~ns}$ & $-0.19^{*}$ & $0.52^{* *}$ & $0.07 \mathrm{~ns}$ & $0.40 * *$ & $0.58^{* *}$ & $0.74 * *$ & 1.00 & $0.38^{* *}$ & $0.74 * *$ & $0.56 * *$ & $0.49 * *$ & $0.49 * *$ & $0.44 * *$ \\
\hline
\end{tabular}




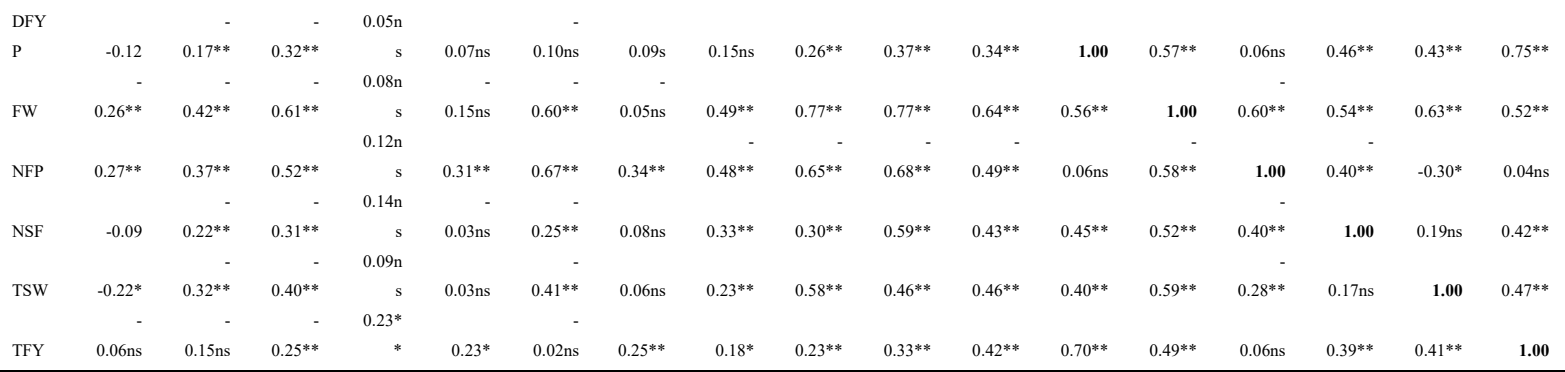

Note: $\mathrm{ns}=$ non Significance $*$ and $* *=$ significant at $5 \%$ and $1 \%$ probability levels, respectively. DFL $=$ days to 50 percent flowering, $\mathrm{DFR}=$ Days to 50 percent fruiting, $\mathrm{DM}=$ days to maturity, $\mathrm{PH}=$ plant height, $\mathrm{CD}=$ canopy diameter, $\mathrm{NPB}=$ Number of primary branches per plant, $\mathrm{SD}=$ Stem diameter, $\mathrm{FPL}=$ Fruit pedicel Length, $\mathrm{FL}=$ Fruit length, $\mathrm{FD}=$ Fruit diameter, FPT $=$ Fruit pericarp thickness, $\mathrm{DFYP}=$ Dry fruit yield per plant, FW= Average single fruit weight, $\mathrm{NFP}=$ Number of Fruit per plant, $\mathrm{NSF}=$ Number of seeds per fruit, $\mathrm{TSW}=$ Thousand seed weight, $\mathrm{TFY}=$ Total fruit yield.

Table 5. Estimates of direct (bold and diagonal) and indirect effect (off diagonal) of different characters on fruit yield of 64 hot pepper genotypes at genotypic level at Mereb Lekhe (northern Ethiopia) in, 2017/18.

\begin{tabular}{|c|c|c|c|c|c|c|c|c|c|c|c|c|c|c|c|c|c|}
\hline Characters & DFL & DFR & DM & $\mathrm{PH}$ & $\mathrm{CD}$ & NPB & SD & FPL & $\mathrm{FL}$ & FD & FPT & DFYP & FW & NFP & NSF & TSW & $\mathrm{rg}$ \\
\hline$\overline{\mathrm{DFL}}$ & \begin{tabular}{|c|}
-0.08 \\
\end{tabular} & 0.06 & $\begin{array}{l}-0.12 \\
\end{array}$ & 0.031 & 0.053 & 0.12 & 0.05 & \begin{tabular}{|c|}
-0.03 \\
\end{tabular} & 0.06 & 0.04 & -0.11 & -0.06 & -0.05 & -0.006 & -0.001 & $\begin{array}{l}-0.04 \\
\end{array}$ & $\begin{array}{l}-0.08 \\
\end{array}$ \\
\hline DFR & -0.06 & 0.08 & -0.15 & 0.027 & 0.045 & 0.16 & 0.05 & -0.05 & 0.09 & 0.07 & -0.16 & -0.08 & -0.07 & -0.008 & -0.002 & -0.06 & -0.13 \\
\hline DM & -0.05 & 0.06 & -0.21 & 0.019 & 0.066 & 0.20 & 0.04 & -0.06 & 0.14 & 0.09 & -0.22 & -0.15 & -0.10 & -0.010 & -0.003 & -0.09 & $-0.28^{*}$ \\
\hline PH & -0.04 & 0.03 & -0.06 & 0.065 & 0.037 & 0.03 & 0.08 & 0.01 & -0.01 & 0.00 & 0.00 & 0.03 & 0.02 & -0.002 & 0.001 & 0.02 & 0.20 \\
\hline $\mathrm{CD}$ & -0.02 & 0.02 & -0.07 & 0.012 & 0.205 & 0.12 & 0.04 & -0.03 & 0.05 & 0.04 & -0.09 & 0.03 & -0.03 & -0.006 & 0.000 & 0.00 & $0.28^{*}$ \\
\hline NPB & -0.03 & 0.04 & -0.14 & 0.007 & 0.080 & 0.31 & 0.03 & -0.08 & 0.14 & 0.09 & -0.22 & -0.05 & -0.10 & -0.013 & -0.002 & -0.09 & -0.02 \\
\hline SD & -0.04 & 0.04 & -0.08 & 0.047 & 0.085 & 0.10 & 0.11 & -0.01 & 0.01 & 0.02 & -0.06 & 0.05 & -0.01 & -0.007 & 0.001 & 0.02 & $0.26^{*}$ \\
\hline FPL & 0.02 & -0.03 & 0.10 & 0.005 & -0.047 & -0.18 & -0.01 & 0.13 & -0.12 & -0.09 & 0.19 & 0.07 & 0.08 & 0.009 & 0.003 & 0.05 & 0.19 \\
\hline FL & 0.02 & -0.04 & 0.15 & 0.003 & -0.056 & -0.22 & -0.01 & 0.08 & -0.20 & -0.11 & 0.25 & 0.12 & 0.13 & 0.012 & 0.003 & 0.11 & $0.25^{*}$ \\
\hline FD & 0.02 & -0.04 & 0.13 & 0.002 & -0.049 & -0.19 & -0.01 & 0.08 & -0.14 & -0.15 & 0.31 & 0.17 & 0.13 & 0.013 & 0.006 & 0.09 & 0.37 \\
\hline FPT & 0.02 & -0.04 & 0.13 & 0.000 & -0.048 & -0.18 & -0.02 & 0.07 & -0.13 & -0.13 & 0.37 & 0.18 & 0.12 & 0.010 & 0.005 & 0.09 & $0.44^{* *}$ \\
\hline DFYP & 0.01 & -0.01 & 0.07 & 0.004 & 0.014 & -0.03 & 0.01 & 0.02 & -0.05 & -0.06 & 0.14 & 0.46 & 0.09 & -0.001 & 0.004 & 0.08 & $0.75^{* *}$ \\
\hline $\mathrm{FW}$ & 0.02 & -0.04 & 0.14 & 0.006 & -0.034 & -0.19 & -0.01 & 0.07 & -0.16 & -0.12 & 0.27 & 0.26 & 0.16 & 0.011 & 0.005 & 0.12 & $0.52^{* *}$ \\
\hline NFP & -0.02 & 0.03 & -0.12 & 0.009 & 0.072 & 0.21 & 0.04 & -0.07 & 0.13 & 0.10 & -0.21 & 0.03 & -0.10 & -0.018 & -0.004 & -0.06 & 0.04 \\
\hline NSF & 0.01 & -0.02 & 0.07 & 0.009 & -0.008 & -0.08 & 0.01 & 0.05 & -0.06 & -0.09 & 0.18 & 0.21 & 0.09 & 0.007 & 0.010 & 0.04 & $0.42^{* *}$ \\
\hline TSW & 0.02 & -0.03 & 0.10 & 0.006 & -0.001 & -0.15 & 0.01 & 0.04 & -0.12 & -0.07 & 0.18 & 0.20 & 0.10 & 0.006 & 0.002 & 0.18 & $0.47^{* *}$ \\
\hline
\end{tabular}

Residual effect $=\mathbf{0 . 5 0} *$ and $* *=$ significant at $5 \%$ and $1 \%$ probability levels, respectively. DFL $=$ days to $50 \%$ flowering, $\mathrm{DFL}=$ days to $50 \%$ fruiting, $\mathrm{DM}=$ days to maturity, $\mathrm{PH}=$ plant height, $\mathrm{CD}=$ canopy diameter, $\mathrm{NPB}=$ number of primary branches per plant, $\boldsymbol{S D}=$ stem diameter, $\boldsymbol{F P L}=$ fruit pedicel length, $\mathrm{FL}=$ fruit length, $\mathrm{FD}=$ fruit diameter, $\mathrm{FPT}=$ fruit pericarp thickness, $\mathrm{DFYP}=$ dry fruit yield per plant, $\mathrm{FW}=$ average single fruit weight, $\mathrm{NFP}=$ number of fruit per plant, $\mathrm{NSF}=$ number of seeds per fruit, $\mathrm{TSW}=$ thousand seed weight and $\mathrm{rg}=$ genotypic coefficient of correlation.

\section{Conflict of Interests}

The authors have not declared any conflict of interests.

\section{Acknowledgements}

The authors grateful appreciate the Tigray Agricultural Research Institute (TARI) and Axum Agricultural Research Center (AxARC) for funding the project. It is also time to thank the staff of Horticulture case team in core process of Horticulture and plant sciences for the execution of the experiment. 


\section{References}

Abrham, S., Mandefro, N., \& Sentayehu, A. (2017). Correlation and Path Coefficient Analysis of Hot Pepper (Capsicum annuum L.) Genotypes for Yield and its Components in Ethiopia. Advances in Crop Science and Technology, 5(3), 2329 -8863.

Allard R.W. (1960). Principles of Plant Breeding. John Wiley, New York. 663p.

AxARc (Axum Agricultural Research Center). (2016). Problem appraisal report. Aksum, Ethiopia. (Unpublished).

Berhanu, Y., Derbew, B., Wosene, G., \& Fedaku, M. (2011). Variability, Heritability and genetic advance in Hot Pepper (Capsicum annum L.) Genotypes in West Shoa, Ethiopia. American-Eurasian Journal of Agriculture \& Environmental Science, 10(4), 587-592.

Birhanu, H. Z. (2017). Genetic Variability and Association of Pod Yield and Related Traits in Hot Pepper (Capsicum annuum L.) Landraces of Ethiopia, MSc thesis Bahirdar Univeresity, Bahir Dar, 75pp.

Burton, G. W., \& Devane, E. H. (1953). Estimating heritability in tall fescue (Festuca arundinacea) from replicated clonal material. Agronomy https://doi.org/10.2134/agronj1953.00021962004500100005x

Chakrabarty S., \& Aminul Islam A. K. M. (2017). Selection Criteria for Improving Yield in Chili (Capsicum annuum L.). Research Article 1-9. https://doi.org/10.1155/2017/5437870

CSA, (Central Statistical Agency). (2017). Agricultural sample survey Report on area and production of major crops of private peasant holdings. The FDRE Statistical bulletin, 1(584). Addis Ababa, Ethiopia.118pp.

Dagnoko, A. S., Niamoye Y., Nadou P. S., Olagorite A., Aminata, D., Kadidiatou, G., Aissata, T., Seriba, K., \& Daoule, D. (2013). Overview of pepper (Capsicum spp.) breeding in West Africa. African Journal of Agricultural Research, 8(13), 1108-1114. https://doi.org/10.5897/AJAR2012.1758

Datta, S., \& Das L. (2013). Characterization and genetic variability analysis in Capsicum annuum L. germplasm. SAARC Journal of Agriculture, 11(1), 91-103. https://doi.org/10.3329/sja.v11i1.18387

Deshmukh, S. N., Basu, M. S., \& Reddy, P. S. (1986). Genetic variability, character association and path coefficient analysis of quantitative traits in Viginia bunch varieties of ground nut. Indian Journal of Agricultural Science, 56, 515-518.

Dewey, D. R., \& Lu, K. H. (1959). A correlation and path coefficient analysis of components of crested wheat grass see $\quad$ production. Agronomy https://doi.org/10.2134/agronj1959.00021962005100090002x

FAO. (2015). Database of agricultural production (FAOSTAT). FAO Statistical Databases: Retrieved from http://faostat.fao.org/default.aspx

Fekadu, M., Singh, H., Lemma, D., Chemeda, F., \& Sigvald, R. (2008). Genetic components and heritability of yield and yield related traits in hot pepper. Research Journal of Agricultural Biological Science, 4, 803-809.

Hasan, M. J., Kulsum, M. U., Ullah M. Z., Manzur, H. M., \& Eleyash, M. M. (2014). Genetic Diversity of some Chili (Capsicum annum L.) Genotypes. International Journal Agriculture Research Innovation \& Technology, 4(1), 32-35. https://doi.org/10.3329/ijarit.v4i1.21088

IBPGR. (1983). Genetic resources of Capsicum a global plan of action. International Board for Plant Genetic Resources. IBPGR Secretariat, Rome.

IPGRI, AVRDC \& CATIE. (1995). Descriptors for Capsicum (Capsicum spp.). International Plant Genetic Resources Institute, Rome, Italy; the Asian Vegetable Research and Development Center, Taipei, Taiwan, and the Centro Agronómico Tropical de Investigación y Enseñanza, Turrialba, Costa Rica. 110pp.

Janaki, M., Naram, N. L., Venkata, R. C., \& Paratpara, M. R. (2015). Assessment of Genetic Variability, Heritability and Genetic Advance for Quantitative Traits in Chilli (Capsicum annuum L.). International Journal of Science, 10(2), 729-733.

Johnson, H. W., Robinson, H. F., \& Comtock, R. E. (1955). Estimates of genetic and environmental variability in soy beans. Agronomy Journal, 47, 314-318. https://doi.org/10.2134/agronj1955.00021962004700070009x

Kadwey, S., Dadiga, A., \& Prajapatis, S. (2015). Genotypes performance and genetic variability studies in hot chilli (capsicum annuum L.). Indian Journal of Agricultural Research, 50(1), 56-60. https://doi.org/10.18805/ijare.v0iOF.7105 
Kumari, V. (2017). Genetic Variability and Character Association for Fruit Yield and Its Attributing Traits in Chilli (Capsicum annuum L.) MSc thesis, Indira Gandhi Krishi Vishwavidhyalaya, Raipur(Chhattisgarh).100pp.

MoANR (Ministry of Agriculture \& Natural Resources). (2016). Plant variety release, protection and Seed Quality Control Directorate. Crop variety Register. Issue No.19. June 2016. Addis Ababa, Ethiopia.

Nsabiyera, V., Logose, M., Ochwo - Ssemakura, M., Sseruwagi, P., Gibson, P., \& Ojiewo, P. (2013). Morphological Characterization of Local and Exotic Hot pepper (Capsicum annuum L.) Collections in Uganda. Bioremediation, Biodiversity and Bioavailability, 7(1), 22-32.

Pickersgill, B. (1997). Genetic Resources and Breeding of Capsicum spp. Euphytica, 96, 129-133. https://doi.org/10.1023/A:1002913228101

Pujar, U. U., Tirakannanavar, S., Jagadeesha, R.C., Gasti, V. D., \& Sandhyarani, N. (2017). Genetic Variability, Heritability, Correlation and Path Analysis in Chilli (Capsicum annuum L.). International Journal Pure Applied Bioscience, 5(5), 579-586. https://doi.org/10.18782/2320-7051.5878

Rosmaina, S., Hasrol, F. Y., Juliyanti, \& Zulfahmi. (2016). Estimation of variability, heritability and genetic advance among local chili pepper genotypes cultivated in peat lands. Bulgarian Journal of Agricultural Science, 22(3), 431-436.

Sahu, L., Trivedi, J., \& Sharma, D. (2016). Genetic variability, heritability and divergence analysis in chilli (Capsicum annuum L.). Plant Archives, 16(1), 445-448.

Saleh, B. K. (2016). Production Status and Genetic Characterization of Eritrean Pepper (Capsicum Spp.) Ph.D Thesis. Jomo Kenyatta University of Agriculture and Technology Jkuat, Kenya, 185pp.

SAS Institute Inc. (2010). Statistical analysis Software version 9.2, Cary, NC: SAS Institute Inc. USA.

Sharma, V. K., Semwal, C. S., \& Uniyal, S. P. (2010). Genetic variability and character association analysis in bell pepper (Capsicum annuum L.). Journal of Horticulture and Forestry, 2(3), 58-65.

Shimeles Aklilu Alemu. (2018). Diversity, Disease Reaction, Heterosis and combining Ability in Hot Pepper (Capsicum annuum L.) Genotypes for Agro-Morphological and Quality Traits in Ethiopia. Ph.D Thesis. Arsi University, Asella, Ethiopia.178pp.

Shimelis, A., Bekele, A., Dagne, W., \& Adefris, T. (2016). Genetic variability and association of characters in Ethiopian hot pepper (Capsicum annuum L.) landraces. Journal of Agricultural Sciences, 61(1), 19-36. https://doi.org/10.2298/JAS1601019A

Silesh, D. (2011). Evaluation of Elite Hot Pepper Varieties (capsicum species) for Growth, dry pod yield and quality under Jimma condition, south west Ethiopia, MSc thesis, Jimma University, Jimma, 58pp.

Singh, B. D. (2001). Plant Breeding: Principles and Methods $6^{\text {th }}$ ed. Kalyani Publishers, New Delhi, India.

Singh, R. K., \& Chaundry, B. D. (1985). Biometrical Methods in Quantitative Genetic Analysis (2nd ed.). Kalayani Publishers, New Delhi-Ludhiana.

Vavilov N. I. (1951). Origin, variation, immunity and breeding of cultivated plants. Chronol Botany, 13, 4-364.

Appendix 1. Mean values for phenological and morphological characters of 64 hot pepper genotypes evaluated under irrigation at Mereb Lekhe (northern Ethiopia) in 2017/18.

\begin{tabular}{|c|c|c|c|c|c|c|c|c|}
\hline No. & Genotypes & $\overline{\text { DFL }}$ & DFR & DM & $\mathrm{PH}$ & $\mathrm{CD}$ & NPB & SD \\
\hline 1 & Acc-1 & $65^{\mathrm{g}-\mathrm{m}}$ & $72^{i-p}$ & $113.5^{p}$ & $60^{a-e}$ & $39.5^{\mathrm{a}-\mathrm{j}}$ & $5.75^{\mathrm{n}-\mathrm{s}}$ & $16^{\mathrm{ab}}$ \\
\hline 2 & Acc-2 & $68^{\mathrm{c}-\mathrm{k}}$ & $79^{\mathrm{a}-\mathrm{g}}$ & $126^{\mathrm{b}-\mathrm{g}}$ & $52.8^{\mathrm{c}-\mathrm{m}}$ & $41.1^{\mathrm{a}-\mathrm{g}}$ & $11^{\mathrm{a}-\mathrm{d}}$ & $13.2^{\mathrm{c}-\mathrm{j}}$ \\
\hline 3 & Acc-3 & $70.5^{\mathrm{a}-\mathrm{h}}$ & $79.5^{\mathrm{a}-\mathrm{f}}$ & $122.5^{\mathrm{d}-1}$ & $66.5^{a}$ & $40.5^{\mathrm{a}-\mathrm{h}}$ & $6.3^{\mathrm{k}-\mathrm{p}}$ & $14.9^{\mathrm{a}-\mathrm{e}}$ \\
\hline 4 & Acc-4 & $64^{i-n}$ & $74^{\mathrm{e}-\mathrm{o}}$ & $116^{\mathrm{m}-\mathrm{p}}$ & $46.3^{\mathrm{j}-\mathrm{o}}$ & $40.2^{\mathrm{a}-\mathrm{i}}$ & $11^{\mathrm{a}-\mathrm{d}}$ & $12.65^{\mathrm{d}-\mathrm{m}}$ \\
\hline 5 & Acc-5 & $74^{\mathrm{a}-\mathrm{c}}$ & $81^{\mathrm{a}-\mathrm{d}}$ & $133^{a}$ & $59.5^{\mathrm{a}-\mathrm{f}}$ & $40.4^{\mathrm{a}-\mathrm{h}}$ & $11.75^{\mathrm{ab}}$ & $14.4^{\mathrm{a}-\mathrm{f}}$ \\
\hline 6 & Acc- 6 & $71^{\mathrm{a}-\mathrm{g}}$ & $82.5^{\mathrm{ab}}$ & $128.5^{\mathrm{a}-\mathrm{c}}$ & $54.3^{\mathrm{c}-\mathrm{m}}$ & $34.9^{\mathrm{j}-\mathrm{o}}$ & $9.8^{\mathrm{a}-\mathrm{g}}$ & $13.5^{\mathrm{c}-\mathrm{h}}$ \\
\hline 7 & Acc-7 & $65^{\mathrm{g}-\mathrm{m}}$ & $77.5^{\mathrm{b}-\mathrm{j}}$ & $126.5^{b-f}$ & $53.3^{\mathrm{c}-\mathrm{m}}$ & $38.3^{\mathrm{b}-1}$ & $7.2^{\mathrm{h}-\mathrm{o}}$ & $13^{\mathrm{c}-1}$ \\
\hline 8 & Acc- 8 & $68.5^{\mathrm{c}-\mathrm{k}}$ & $77.5^{\mathrm{b}-\mathrm{j}}$ & $127.5^{\mathrm{a}-\mathrm{d}}$ & $60.7^{\mathrm{a}-\mathrm{d}}$ & $42.9^{\mathrm{ab}}$ & $10^{\mathrm{a}-\mathrm{f}}$ & $15.25^{\mathrm{a}-\mathrm{c}}$ \\
\hline 9 & Acc-9 & $75.5^{\mathrm{ab}}$ & $80^{\mathrm{a}-\mathrm{e}}$ & $130.5^{\mathrm{ab}}$ & $60^{\mathrm{a}-\mathrm{e}}$ & $37.7^{\mathrm{c}-\mathrm{m}}$ & $11.6^{\mathrm{ab}}$ & $13.85^{\mathrm{a}-\mathrm{g}}$ \\
\hline 10 & Acc- 10 & $69.5^{b-j}$ & $81^{\mathrm{a}-\mathrm{d}}$ & $123.5^{\mathrm{d}-\mathrm{k}}$ & $55.4^{\mathrm{b}-1}$ & $37.6^{\mathrm{d}-\mathrm{m}}$ & $10.9^{\mathrm{a}-\mathrm{e}}$ & $14.4^{\mathrm{a}-\mathrm{f}}$ \\
\hline 11 & Acc-11 & $69.5^{b-j}$ & $76.5^{\mathrm{b}-1}$ & $113.5^{\mathrm{p}}$ & $54.8^{\mathrm{b}-\mathrm{m}}$ & $33.1^{\mathrm{m}-\mathrm{o}}$ & $5.6^{\mathrm{n}-\mathrm{s}}$ & $13.05^{\mathrm{c}-\mathrm{k}}$ \\
\hline 12 & Acc-12 & $67^{\mathrm{d}-\mathrm{m}}$ & $78^{\mathrm{b}-\mathrm{i}}$ & $127^{\mathrm{b}-\mathrm{e}}$ & $57.3^{\mathrm{a}-\mathrm{h}}$ & $42^{a-d}$ & $11.8^{\mathrm{a}}$ & $11.1^{\mathrm{h}-\mathrm{o}}$ \\
\hline 13 & Acc-13 & $65^{\mathrm{g}-\mathrm{m}}$ & $74.5^{\mathrm{e}-\mathrm{n}}$ & $117.5^{1-p}$ & $51.5^{\mathrm{d}-\mathrm{m}}$ & $33.85^{1-o}$ & $5.4^{\mathrm{n}-\mathrm{s}}$ & $11.7^{\mathrm{g}-\mathrm{o}}$ \\
\hline 14 & Acc-14 & $73^{a-d}$ & $78^{\mathrm{b}-\mathrm{i}}$ & $129^{a-c}$ & $53.5^{\mathrm{c}-\mathrm{m}}$ & $42.3^{\mathrm{a}-\mathrm{c}}$ & $11.5 \mathrm{a}-\mathrm{c}$ & $15^{a-d}$ \\
\hline 15 & Acc- 15 & $70.5^{\mathrm{a}-\mathrm{h}}$ & $77.5^{b-j}$ & $126^{\mathrm{b}-\mathrm{g}}$ & $54.1^{\mathrm{c}-\mathrm{m}}$ & $43.3^{\mathrm{a}}$ & $6.3 \mathrm{k}-\mathrm{p}$ & $13.3^{\mathrm{c}-\mathrm{j}}$ \\
\hline
\end{tabular}




\begin{tabular}{|c|c|c|c|c|c|c|c|c|}
\hline 16 & Acc-16 & $65.5^{\mathrm{f}-\mathrm{n}}$ & $74.5^{\mathrm{e}-\mathrm{n}}$ & $121.5^{\mathrm{e}-\mathrm{m}}$ & $56.2^{b-j}$ & $36.45^{\mathrm{g}-\mathrm{o}}$ & $4.80-\mathrm{s}$ & $12.9^{\mathrm{c}-\mathrm{m}}$ \\
\hline 17 & Acc- 28336 & $70^{\mathrm{b}-\mathrm{i}}$ & $79^{\mathrm{a}-\mathrm{g}}$ & $127^{\mathrm{b}-\mathrm{e}}$ & $58.4^{\mathrm{a}-\mathrm{g}}$ & $39.3^{\mathrm{a}-\mathrm{j}}$ & $9.2 b-\mathrm{i}$ & $12.8^{\mathrm{d}-\mathrm{n}}$ \\
\hline 18 & Acc- 230800 & $68.5^{\mathrm{c}-\mathrm{k}}$ & $77^{\mathrm{b}-\mathrm{k}}$ & $121.5^{\mathrm{e}-\mathrm{m}}$ & $56.1^{\mathrm{b}-\mathrm{k}}$ & $39.2^{\mathrm{a}-\mathrm{j}}$ & $9 c-j$ & $12.25^{\mathrm{f}-\mathrm{o}}$ \\
\hline 19 & Acc-28337 & $66^{\mathrm{f}-\mathrm{n}}$ & $77^{\mathrm{b}-\mathrm{k}}$ & $120.5^{\mathrm{g}-\mathrm{m}}$ & $54.3^{\mathrm{c}-\mathrm{m}}$ & $35.6^{\mathrm{i}-\mathrm{o}}$ & $3.6 \mathrm{rs}$ & $12.75^{\mathrm{d}-\mathrm{n}}$ \\
\hline 20 & Acc-229699 & $65.5^{\mathrm{f}-\mathrm{n}}$ & $75.5^{\mathrm{c}-\mathrm{m}}$ & $124.5^{\mathrm{c}-\mathrm{i}}$ & $54.6^{\mathrm{c}-\mathrm{m}}$ & $36.9^{\mathrm{f}-\mathrm{o}}$ & $11.8 \mathrm{a}$ & $12.75^{\mathrm{d}-\mathrm{n}}$ \\
\hline 21 & Acc-212912 & $70.5^{\mathrm{a}-\mathrm{h}}$ & $78.5^{\mathrm{a}-\mathrm{h}}$ & $120^{\mathrm{h}-\mathrm{n}}$ & $60.1^{\mathrm{a}-\mathrm{e}}$ & $41^{\mathrm{a}-\mathrm{g}}$ & $8.4 \mathrm{e}-\mathrm{m}$ & $14.9^{\mathrm{a}-\mathrm{e}}$ \\
\hline 22 & Acc-9097 & $61^{\mathrm{m}-\mathrm{o}}$ & $72^{i-p}$ & $123.5^{\mathrm{c}-\mathrm{k}}$ & $37.1^{\circ}$ & $39^{a-k}$ & $6.3 \mathrm{k}-\mathrm{p}$ & $11^{\mathrm{i}-\mathrm{o}}$ \\
\hline 23 & Acc-9084 & $57.5^{\circ}$ & $68^{\mathrm{op}}$ & $122.5^{\mathrm{d}-1}$ & $53.5^{\mathrm{c}-\mathrm{m}}$ & $36^{\mathrm{h}-\mathrm{o}}$ & $8.8 \mathrm{~d}-\mathrm{k}$ & $12.65^{\mathrm{d}-\mathrm{m}}$ \\
\hline 24 & Acc-229697 & $68^{\mathrm{c}-\mathrm{k}}$ & $77^{\mathrm{b}-\mathrm{k}}$ & $124^{\mathrm{c}-\mathrm{j}}$ & $50.1^{\mathrm{e}-\mathrm{m}}$ & $32.4^{\circ}$ & $9.7 \mathrm{a}-\mathrm{h}$ & $11.75^{\mathrm{g}-\mathrm{o}}$ \\
\hline 25 & Acc-212913 & $64^{i-n}$ & $71.5^{\mathrm{j}-\mathrm{p}}$ & $119.5^{\mathrm{i}-\mathrm{o}}$ & $55.8^{\mathrm{b}-\mathrm{k}}$ & $41.5^{\mathrm{a}-\mathrm{e}}$ & $3.9 q-s$ & $13.9^{\mathrm{a}-\mathrm{g}}$ \\
\hline 26 & Acc- 229700 & $66.5^{\mathrm{e}-\mathrm{m}}$ & $78.5^{\mathrm{a}-\mathrm{h}}$ & $125.5^{\mathrm{b}-\mathrm{h}}$ & $50.9^{\mathrm{d}-\mathrm{m}}$ & $33.5^{\mathrm{m}-\mathrm{o}}$ & $8.7 \mathrm{~d}-1$ & $13.35^{\mathrm{c}-\mathrm{i}}$ \\
\hline 27 & Acc- 8995 & $70.5^{a-h}$ & $77^{\mathrm{b}-\mathrm{k}}$ & $128.5^{\mathrm{a}-\mathrm{c}}$ & $52.8^{\mathrm{c}-\mathrm{m}}$ & $39.1^{\mathrm{a}-\mathrm{j}}$ & $11^{\mathrm{a}-\mathrm{d}}$ & $12.6^{\mathrm{d}-\mathrm{n}}$ \\
\hline 28 & Acc-9085 & $67.5^{\mathrm{d}-1}$ & $75^{\mathrm{d}-\mathrm{m}}$ & $120^{\mathrm{h}-\mathrm{n}}$ & $46.3^{\mathrm{j}-\mathrm{o}}$ & $35.1^{\mathrm{j}-\mathrm{o}}$ & $6.6^{\mathrm{j}-\mathrm{p}}$ & $10.75^{\mathrm{k}-\mathrm{o}}$ \\
\hline 29 & Acc-230798 & $64^{i-n}$ & $71.5^{\mathrm{i}-\mathrm{p}}$ & $116.5^{1-p}$ & $47.6^{\mathrm{h}-\mathrm{m}}$ & $35.1^{\mathrm{k}-\mathrm{o}}$ & $3.7^{\mathrm{rs}}$ & $11^{\mathrm{i}-\mathrm{o}}$ \\
\hline 30 & Acc-230799 & $72.5^{\mathrm{a}-\mathrm{e}}$ & $79^{a-g}$ & $126^{\mathrm{b}-\mathrm{g}}$ & $52.7^{\mathrm{c}-\mathrm{m}}$ & $38.9^{\mathrm{a}-\mathrm{k}}$ & $7.8^{\mathrm{f}-\mathrm{n}}$ & $11.8^{\mathrm{g}-\mathrm{o}}$ \\
\hline 31 & Acc- 236436 & $67^{\mathrm{d}-\mathrm{m}}$ & $77.5^{b-j}$ & $125.5^{\mathrm{b}-\mathrm{h}}$ & $55.5^{\mathrm{b}-1}$ & $33.2^{\mathrm{m}-\mathrm{o}}$ & $5.25^{\mathrm{n}-\mathrm{s}}$ & $12.2^{\mathrm{f}-\mathrm{o}}$ \\
\hline 32 & Acc- 229698 & $62.5^{\mathrm{k}-\mathrm{o}}$ & $70.5^{1-p}$ & $118^{\mathrm{k}-\mathrm{p}}$ & $49.5^{\mathrm{f}-\mathrm{m}}$ & $35^{\mathrm{j}-\mathrm{o}}$ & $3.6^{\mathrm{rs}}$ & $12.25^{\mathrm{f}-\mathrm{o}}$ \\
\hline 33 & Acc-229701 & $63.5^{\mathrm{j}-\mathrm{o}}$ & $71^{\mathrm{k}-\mathrm{p}}$ & $117^{1-p}$ & $37.5^{\text {no }}$ & $37.5^{\mathrm{d}-\mathrm{n}}$ & $9.7^{\mathrm{a}-\mathrm{h}}$ & $10.4^{\text {no }}$ \\
\hline 34 & Acc- 237528 & $71^{\mathrm{a}-\mathrm{g}}$ & $80^{\mathrm{a}-\mathrm{e}}$ & $127.5^{\mathrm{a}-\mathrm{d}}$ & $47.1^{\mathrm{h}-\mathrm{m}}$ & $35.2^{\mathrm{j}-\mathrm{o}}$ & $9.7^{\mathrm{a}-\mathrm{h}}$ & $10.9^{\mathrm{j}-\mathrm{o}}$ \\
\hline 35 & Acc-9102 & $64.5^{\mathrm{h}-\mathrm{m}}$ & $72.5^{\mathrm{h}-\mathrm{p}}$ & $124.5^{\mathrm{c}-\mathrm{i}}$ & $59.4^{\mathrm{a}-\mathrm{g}}$ & $35^{\mathrm{j}-\mathrm{o}}$ & $6.7^{\mathrm{i}-\mathrm{p}}$ & $13.65^{\mathrm{b}-\mathrm{g}}$ \\
\hline 36 & Acc-9094 & $71.5^{\mathrm{a}-\mathrm{f}}$ & $76.5^{b-1}$ & $122.5^{\mathrm{d}-1}$ & $50.4^{\mathrm{d}-\mathrm{m}}$ & $34.4^{\mathrm{k}-\mathrm{o}}$ & $7.05^{\mathrm{i}-\mathrm{p}}$ & $12.25^{\mathrm{f}-\mathrm{o}}$ \\
\hline 37 & Acc-9098 & $63.5^{\mathrm{j}-\mathrm{o}}$ & $78^{\mathrm{b}-\mathrm{i}}$ & $127.5^{\mathrm{a}-\mathrm{d}}$ & $54^{\mathrm{c}-\mathrm{m}}$ & $37.6^{\mathrm{d}-\mathrm{m}}$ & $8.6^{\mathrm{d}-1}$ & $12.9^{c-m}$ \\
\hline 38 & Acc-9104 & $63.5^{\mathrm{j}-\mathrm{o}}$ & $77.5^{\mathrm{b}-\mathrm{j}}$ & $127^{\mathrm{b}-\mathrm{e}}$ & $45.7^{\mathrm{k}-\mathrm{o}}$ & $41.6^{\mathrm{a}-\mathrm{e}}$ & $10.5^{\mathrm{a}-\mathrm{e}}$ & $12.25^{\mathrm{f}-\mathrm{o}}$ \\
\hline 39 & Acc-9099 & $70.5^{\mathrm{a}-\mathrm{h}}$ & $79^{a-g}$ & $128.5^{\mathrm{a}-\mathrm{c}}$ & $46.8^{\mathrm{i}-\mathrm{o}}$ & $35.1^{\mathrm{j}-\mathrm{o}}$ & $8.7^{\mathrm{d}-1}$ & $12.75^{\mathrm{d}-\mathrm{n}}$ \\
\hline 40 & Acc-9082 & $67^{\mathrm{d}-\mathrm{m}}$ & $74^{\mathrm{e}-\mathrm{o}}$ & $119^{i-p}$ & $52^{\mathrm{c}-\mathrm{m}}$ & $36.1^{\mathrm{h}-\mathrm{o}}$ & $5.25^{\mathrm{n}-\mathrm{s}}$ & $12.5^{\mathrm{e}-\mathrm{n}}$ \\
\hline 41 & Acc-9101 & $67^{\mathrm{d}-\mathrm{m}}$ & $71.5^{\mathrm{j}-\mathrm{p}}$ & $122^{\mathrm{d}-1}$ & $57.3^{\mathrm{a}-\mathrm{h}}$ & $43.1^{\mathrm{a}}$ & $7.7^{\mathrm{f}-\mathrm{n}}$ & $13.35^{\mathrm{c}-\mathrm{i}}$ \\
\hline 42 & Acc-9086 & $70^{\mathrm{b}-\mathrm{i}}$ & $80^{\mathrm{a}-\mathrm{e}}$ & $129^{a-c}$ & $52.7^{\mathrm{c}-\mathrm{m}}$ & $42.5^{\mathrm{ab}}$ & $7.3^{\mathrm{g}-\mathrm{o}}$ & $13.2^{\mathrm{c}-\mathrm{j}}$ \\
\hline 43 & Acc- 229696 & $73^{a-d}$ & $82.5^{\mathrm{ab}}$ & $127.5^{\mathrm{a}-\mathrm{d}}$ & $55.3^{\mathrm{b}-\mathrm{m}}$ & $36.6^{\mathrm{g}-\mathrm{o}}$ & $7.7^{\mathrm{f}-\mathrm{n}}$ & $13.6^{\mathrm{c}-\mathrm{g}}$ \\
\hline 44 & Acc-9106 & $66^{\mathrm{f}-\mathrm{n}}$ & $80^{\mathrm{a}-\mathrm{e}}$ & $122.5^{\mathrm{d}-1}$ & $51.8^{\mathrm{d}-\mathrm{m}}$ & $35.55^{\mathrm{i}-\mathrm{o}}$ & $8.7^{\mathrm{d}-1}$ & $12.35^{\mathrm{f}-\mathrm{n}}$ \\
\hline 45 & Acc-9007 & $70^{\mathrm{b}-\mathrm{i}}$ & $77.5^{\mathrm{b}-\mathrm{j}}$ & $129^{a-c}$ & $60.8^{a-c}$ & $35.9^{\mathrm{h}-\mathrm{o}}$ & $8.6^{\mathrm{d}-1}$ & $14^{\mathrm{a}-\mathrm{g}}$ \\
\hline 46 & Acc-9107 & $71.5^{\mathrm{a}-\mathrm{f}}$ & $76.5^{\mathrm{b}-1}$ & $126^{\mathrm{b}-\mathrm{g}}$ & $52.7^{\mathrm{c}-\mathrm{m}}$ & $37^{\mathrm{e}-\mathrm{o}}$ & $5^{\mathrm{o}-\mathrm{s}}$ & $12.05^{\mathrm{f}-\mathrm{n}}$ \\
\hline 47 & Acc- 28334 & $64.5^{\mathrm{h}-\mathrm{m}}$ & $70.5^{1-p}$ & $122.5^{\mathrm{d}-1}$ & $50.7^{\mathrm{d}-\mathrm{m}}$ & $33.9^{1-\mathrm{o}}$ & $4.6^{\mathrm{p}-\mathrm{s}}$ & $13.2^{\mathrm{c}-\mathrm{j}}$ \\
\hline 48 & Acc- 48 & $61.5^{1-\mathrm{o}}$ & $67.5^{p}$ & $117^{1-p}$ & $47.7^{\mathrm{h}-\mathrm{m}}$ & $37.25^{\mathrm{e}-\mathrm{n}}$ & $3.6^{\mathrm{rs}}$ & $10.55^{\mathrm{m}-\mathrm{o}}$ \\
\hline 49 & Acc-49 & $63.5^{\mathrm{j}-\mathrm{o}}$ & $67.5^{p}$ & $114.5^{n-p}$ & $45.3^{1-\mathrm{o}}$ & $39^{a-k}$ & $3.5^{\mathrm{s}}$ & $10.75^{\mathrm{k}-\mathrm{o}}$ \\
\hline 50 & Acc-229694 & $65.5^{\mathrm{f}-\mathrm{n}}$ & $74.5^{\mathrm{e}-\mathrm{n}}$ & $117^{1-p}$ & $56.2^{\mathrm{b}-\mathrm{j}}$ & $37.5^{\mathrm{d}-\mathrm{n}}$ & $3.5^{\mathrm{s}}$ & $13.55^{\mathrm{c}-\mathrm{g}}$ \\
\hline 51 & Acc-51 & $68^{\mathrm{c}-\mathrm{k}}$ & $74.5^{e-n}$ & $119.5^{\mathrm{i}-\mathrm{o}}$ & $57.5^{\mathrm{a}-\mathrm{g}}$ & $33.3^{\mathrm{m}-\mathrm{o}}$ & $3.6^{\mathrm{rs}}$ & $12.75^{\mathrm{d}-\mathrm{n}}$ \\
\hline 52 & Acc-52 & $66.5^{\mathrm{e}-\mathrm{m}}$ & $77^{\mathrm{b}-\mathrm{k}}$ & $121.5^{\mathrm{e}-\mathrm{m}}$ & $47.3^{\mathrm{h}-\mathrm{m}}$ & $37.5^{\mathrm{d}-\mathrm{n}}$ & $3.4^{\mathrm{s}}$ & $11.85^{\mathrm{g}-\mathrm{o}}$ \\
\hline 53 & Acc-9093 & $62.5^{\mathrm{k}-\mathrm{o}}$ & $68.5^{\mathrm{n}-\mathrm{p}}$ & $119^{\mathrm{i}-\mathrm{p}}$ & $54.1^{\mathrm{c}-\mathrm{m}}$ & $32.95^{\text {no }}$ & $6.4^{1-q}$ & $11.6^{\mathrm{g}-\mathrm{o}}$ \\
\hline 54 & Acc-229692 & $67^{\mathrm{d}-\mathrm{m}}$ & $73.5^{f-p}$ & $118.5^{\mathrm{j}-\mathrm{p}}$ & $51.6^{\mathrm{d}-\mathrm{m}}$ & $36.2^{\mathrm{h}-\mathrm{o}}$ & $3.9^{\mathrm{q}-\mathrm{s}}$ & $12.3^{\mathrm{f}-\mathrm{n}}$ \\
\hline 55 & Acc-55 & $65^{\mathrm{g}-\mathrm{m}}$ & $69.5^{\mathrm{m}-\mathrm{p}}$ & $117^{1-p}$ & $52.5^{\mathrm{c}-\mathrm{m}}$ & $37^{\mathrm{e}-\mathrm{o}}$ & $4^{q-s}$ & $12.3^{\mathrm{f}-\mathrm{n}}$ \\
\hline 56 & Acc-56 & $68.5^{\mathrm{c}-\mathrm{k}}$ & $71.5^{\mathrm{j}-\mathrm{p}}$ & $116.5^{1-p}$ & $56.1^{\mathrm{b}-\mathrm{k}}$ & $35.55^{\mathrm{i}-\mathrm{o}}$ & $5.5^{\mathrm{n}-\mathrm{s}}$ & $11.6^{\mathrm{g}-\mathrm{o}}$ \\
\hline 57 & Acc-57 & $64^{i-n}$ & $72.5^{\mathrm{h}-\mathrm{p}}$ & $114^{\mathrm{p}}$ & $47.2^{\mathrm{h}-\mathrm{m}}$ & $36^{\mathrm{h}-\mathrm{o}}$ & $3.5^{\mathrm{s}}$ & $10.6^{1-o}$ \\
\hline 58 & Acc-58 & $69^{c-j}$ & $73^{g-p}$ & $119.5^{\mathrm{i}-\mathrm{o}}$ & $51.6^{\mathrm{d}-\mathrm{m}}$ & $37.5^{\mathrm{d}-\mathrm{n}}$ & $3.5^{\mathrm{s}}$ & $12.3^{\mathrm{f}-\mathrm{n}}$ \\
\hline 59 & Acc-59 & $75.5^{\mathrm{ab}}$ & $81.5^{\mathrm{a}-\mathrm{c}}$ & $130.5^{\mathrm{ab}}$ & $59.6^{\mathrm{a}-\mathrm{f}}$ & $43.4^{\mathrm{a}}$ & $10.1^{\mathrm{a}-\mathrm{f}}$ & $16.05^{\mathrm{a}}$ \\
\hline 60 & Acc- 23880 & $63.5^{\mathrm{j}-\mathrm{o}}$ & $72.5^{\mathrm{h}-\mathrm{p}}$ & $120^{\mathrm{h}-\mathrm{n}}$ & $49^{g-m}$ & $35.6^{\mathrm{i}-\mathrm{o}}$ & $5.9^{\mathrm{m}-\mathrm{s}}$ & $10.9^{\mathrm{j}-\mathrm{o}}$ \\
\hline 61 & Acc-61 & $60.5^{\text {no }}$ & $70.5^{1-p}$ & $118^{\mathrm{k}-\mathrm{p}}$ & $44.9^{\mathrm{m}-\mathrm{o}}$ & $36^{\mathrm{h}-\mathrm{o}}$ & $3.6^{\mathrm{rs}}$ & $9.85^{\circ}$ \\
\hline 62 & Acc- 62 & $62.5^{\mathrm{k}-\mathrm{o}}$ & $74^{\mathrm{e}-\mathrm{o}}$ & $120^{\mathrm{h}-\mathrm{n}}$ & $56.8^{\mathrm{a}-\mathrm{i}}$ & $33.3^{\mathrm{m}-\mathrm{o}}$ & $3.95^{\mathrm{q}-\mathrm{s}}$ & $11.95^{\mathrm{g}-\mathrm{n}}$ \\
\hline 63 & Acc- 63 & $76.5^{\mathrm{a}}$ & $84.5^{\mathrm{a}}$ & $126^{\mathrm{b}-\mathrm{g}}$ & $65^{\mathrm{ab}}$ & $37.4^{\mathrm{d}-\mathrm{n}}$ & $6.2^{1-r}$ & $13.7^{\mathrm{a}-\mathrm{g}}$ \\
\hline \multirow[t]{3}{*}{64} & Acc-64 & $66^{\mathrm{f}-\mathrm{n}}$ & $76.5^{b-1}$ & $121^{\mathrm{f}-\mathrm{m}}$ & $62.3^{a-c}$ & $35^{\mathrm{j}-\mathrm{o}}$ & $3.6 \mathrm{r}^{\mathrm{s}}$ & $13.7^{\mathrm{a}-\mathrm{g}}$ \\
\hline & Mean & 62.27 & 75.68 & 122.6 & 53.29 & 37.38 & 7.1 & 12.7 \\
\hline & $\mathrm{CV}(\%)$ & 3.8 & 3.3 & 2 & 7.8 & 5 & 15 & 7.7 \\
\hline
\end{tabular}

Means followed by the same letter in the same column are not significantly different. CV (\%) = coefficient of variation, $\mathrm{DFL}=$ days to $50 \%$ flowering, $\mathrm{DFR}=$ days to $50 \%$ fruiting $\mathrm{DM}=$ days to maturity, $\mathrm{PH}=$ plant height, $\mathrm{CD}=$ canopy diameter, $\mathrm{NPB}=$ number of primary branches per plant, $\mathrm{SD}=$ stem diameter.

Appendix 2. Mean performance for fruit yield and fruit characteristics of 64 hot pepper genotypes evaluated at Mereb Lekhe (northern Ethiopia) in, 2017/18

\begin{tabular}{|c|c|c|c|c|c|c|c|c|c|c|c|c|c|}
\hline No. & Genotypes & FPL & FL & FD & FPT & FW & NFP & NSF & TSW & DFYP & MFY & UNMY & TFY \\
\hline 1 & Acc-1 & $4.05^{\mathrm{a}-\mathrm{g}}$ & $16.75 \mathrm{a}$ & $23.25^{\mathrm{d}-\mathrm{f}}$ & $2.3^{\mathrm{a}-\mathrm{g}}$ & $6.6^{\mathrm{a}-\mathrm{c}}$ & $26^{\mathrm{j}-\mathrm{m}}$ & $136.5^{\mathrm{n}-\mathrm{p}}$ & $6.55^{\mathrm{a}-\mathrm{d}}$ & $128.5^{\mathrm{e}}$ & $3.25^{\mathrm{c}-\mathrm{d}}$ & $0.125^{\mathrm{qr}}$ & $3.38^{\mathrm{bc}}$ \\
\hline 2 & Acc-2 & $2.67^{0-\mathrm{t}}$ & $6.2^{0-u}$ & $11.21^{x}$ & $1.7^{\mathrm{k}}$ & $2.41^{\mathrm{p}-\mathrm{u}}$ & $53.15^{\mathrm{ab}}$ & $105.3^{\mathrm{wx}}$ & $5.8^{\mathrm{c}-\mathrm{j}}$ & $106^{i-1}$ & $2.67^{\mathrm{c}-\mathrm{j}}$ & $0.24^{\mathrm{e}-\mathrm{m}}$ & $2.91^{\mathrm{c}-\mathrm{j}}$ \\
\hline 3 & Acc-3 & $4.1^{\mathrm{a}-\mathrm{f}}$ & $11^{\mathrm{e}-\mathrm{j}}$ & $29.4^{\mathrm{ab}}$ & $2.3^{\mathrm{a}-\mathrm{g}}$ & $6.3^{\mathrm{a}-\mathrm{d}}$ & $19.25^{\mathrm{o-r}}$ & $221^{\mathrm{b}}$ & $6.45^{\mathrm{a}-\mathrm{e}}$ & $167.5^{\mathrm{ab}}$ & $3.855^{\mathrm{ab}}$ & $0.41^{\mathrm{a}}$ & $4.27^{\mathrm{a}}$ \\
\hline 4 & Acc-4 & $2.8^{\mathrm{n}-\mathrm{t}}$ & $7.52^{\mathrm{no}}$ & $18.72^{\mathrm{k}-\mathrm{m}}$ & $2.3^{\mathrm{a}-\mathrm{g}}$ & $2.95^{\mathrm{k}-\mathrm{r}}$ & $34.6^{\mathrm{e}}$ & $188^{\mathrm{d}}$ & $5.8^{\mathrm{c}-\mathrm{j}}$ & $168^{\mathrm{ab}}$ & $4.34^{\mathrm{a}}$ & $0.21^{\mathrm{i}-\mathrm{r}}$ & $4.55^{\mathrm{a}}$ \\
\hline 5 & Acc-5 & $3.4^{\mathrm{g}-\mathrm{n}}$ & $4.56^{v-x}$ & $15.14^{\mathrm{p}-\mathrm{v}}$ & $1.85^{\mathrm{h}-\mathrm{k}}$ & $2.185^{q-u}$ & $55.5^{\mathrm{a}}$ & $111^{\mathrm{u}-\mathrm{w}}$ & $5.7^{\mathrm{d}-\mathrm{j}}$ & $105.5^{\mathrm{i}-\mathrm{I}}$ & $2.85^{\mathrm{chh}}$ & $0.29^{c-i}$ & $3.14^{\mathrm{c}-\mathrm{f}}$ \\
\hline
\end{tabular}




\begin{tabular}{|c|c|c|c|c|c|c|c|c|c|c|c|c|c|}
\hline 6 & Acc-6 & $2.32^{t}$ & $5.08^{s-x}$ & $15.11^{0-\mathrm{v}}$ & $1.7^{\mathrm{k}}$ & $3.7^{\mathrm{h}-\mathrm{m}}$ & $44.3^{\mathrm{c}}$ & $147.4^{\mathrm{j}-\mathrm{m}}$ & $6.5^{\mathrm{a}-\mathrm{d}}$ & $143^{\mathrm{cd}}$ & $2.465^{\mathrm{c}-\mathrm{m}}$ & $0.16^{1-\mathrm{r}}$ & $2.63^{\mathrm{c}-\mathrm{n}}$ \\
\hline 7 & Acc-7 & $3.73^{\mathrm{d}-\mathrm{j}}$ & $11.2^{\mathrm{d}-\mathrm{i}}$ & $15.36^{0-t}$ & $1.82^{i-k}$ & $2.92^{\mathrm{k}-\mathrm{r}}$ & $29.3^{\mathrm{f}-\mathrm{k}}$ & $118.8^{s-v}$ & $6^{\mathrm{b}-\mathrm{i}}$ & $83.5^{0-q}$ & $1.9^{\mathrm{i}-\mathrm{o}}$ & $0.13^{\mathrm{p}-\mathrm{r}}$ & $2^{j-0}$ \\
\hline 8 & Acc- 8 & $3.05^{\mathrm{k}-\mathrm{r}}$ & $4.39^{w x}$ & $12.01^{\mathrm{v}-\mathrm{x}}$ & $1.95^{\mathrm{f}-\mathrm{k}}$ & $2.235^{q-u}$ & $50.9^{\mathrm{ab}}$ & $138.5^{\mathrm{m}-\mathrm{o}}$ & $5.9^{\mathrm{b}-\mathrm{j}}$ & $102.5^{\mathrm{j}-1}$ & $2.88^{\mathrm{c}-\mathrm{h}}$ & $0.2^{\mathrm{i}-\mathrm{r}}$ & $3.1^{\mathrm{c}-\mathrm{g}}$ \\
\hline 9 & Acc-9 & $2.65^{0-t}$ & $6.49^{o-t}$ & $14.06^{\mathrm{p}-\mathrm{x}}$ & $1.85^{\mathrm{h}-\mathrm{k}}$ & $2.205^{\mathrm{q}-\mathrm{u}}$ & $31.5^{\mathrm{c}-\mathrm{h}}$ & $116.5^{\mathrm{t}-\mathrm{v}}$ & $4.6^{1-\mathrm{p}}$ & $63.5^{\mathrm{t}-\mathrm{v}}$ & $2.02^{\mathrm{h}-\mathrm{n}}$ & $0.25^{\mathrm{e}-1}$ & $2.27^{\mathrm{f}-\mathrm{o}}$ \\
\hline 10 & Acc-10 & $3.25^{\mathrm{i}-\mathrm{o}}$ & $10.25^{\mathrm{h}-\mathrm{l}}$ & $12.4^{t-x}$ & $1.9^{g-k}$ & $1.55^{\mathrm{u}}$ & $52.9^{\mathrm{ab}}$ & $110^{\mathrm{u}-\mathrm{w}}$ & $5.1^{\mathrm{h}-\mathrm{n}}$ & $118.5^{\mathrm{e}-\mathrm{h}}$ & $2.56^{\mathrm{c}-1}$ & $0.14^{\text {o-r }}$ & $2.7^{\mathrm{c}-\mathrm{m}}$ \\
\hline 11 & Acc-11 & $4.25^{\mathrm{a}-\mathrm{e}}$ & $14.5^{\mathrm{b}}$ & $23.1^{\mathrm{d}-\mathrm{f}}$ & $2.25^{\mathrm{b}-\mathrm{h}}$ & $6.325^{\mathrm{a}-\mathrm{d}}$ & $23.4^{1-\mathrm{p}}$ & $145.5^{\mathrm{k}-\mathrm{n}}$ & $6.6^{\mathrm{a}-\mathrm{d}}$ & $126.5^{\mathrm{e}}$ & $2.64^{\mathrm{c}-\mathrm{j}}$ & $0.12^{\mathrm{r}}$ & $2.8^{\mathrm{c}-1}$ \\
\hline 12 & Acc-12 & $2.67^{0-t}$ & $4.41^{\mathrm{wx}}$ & $12.89^{s-x}$ & $1.85^{\mathrm{h}-\mathrm{k}}$ & $2.21^{\mathrm{q}-\mathrm{u}}$ & $31.25^{\mathrm{e}-\mathrm{i}}$ & $109.5^{\mathrm{vw}}$ & $4.2^{\mathrm{n}-\mathrm{p}}$ & $87^{0-q}$ & $2.37^{\mathrm{d}-\mathrm{m}}$ & $0.22^{\mathrm{h}-\mathrm{n}}$ & $2.59^{\mathrm{c}-\mathrm{n}}$ \\
\hline 13 & Acc-13 & $2.75^{\mathrm{n}-\mathrm{t}}$ & $8.23^{\mathrm{mn}}$ & $16.03^{\mathrm{o-r}}$ & $1.94^{\mathrm{f}-\mathrm{k}}$ & $2.751-\mathrm{s}$ & $26.3^{\mathrm{i}-\mathrm{m}}$ & $110.2^{\mathrm{u}-\mathrm{w}}$ & $5.35^{\mathrm{f}-\mathrm{m}}$ & $54.5^{\mathrm{v}}$ & $1.63^{\mathrm{m}-\mathrm{o}}$ & $0.16^{1-\mathrm{r}}$ & $1.78^{\mathrm{n}-\mathrm{p}}$ \\
\hline 14 & Acc-14 & $2.52^{\mathrm{r}-\mathrm{t}}$ & $5.25^{\mathrm{t}-\mathrm{x}}$ & $12.94^{s-x}$ & $1.75^{\mathrm{jk}}$ & $2.51^{\mathrm{n}-\mathrm{u}}$ & $43.15^{\mathrm{cd}}$ & $94^{y}$ & $5.4^{\mathrm{e}-1}$ & $86^{0-q}$ & $2.56^{\mathrm{d}-1}$ & $0.24^{\mathrm{f}-\mathrm{n}}$ & $2.79^{\mathrm{c}-\mathrm{k}}$ \\
\hline 15 & Acc-15 & $3^{1-s}$ & $7^{\mathrm{n}-\mathrm{p}}$ & $12.6^{t-x}$ & $1.8^{\mathrm{i}-\mathrm{k}}$ & $2.38^{\mathrm{p}-\mathrm{u}}$ & $42.6^{\mathrm{cd}}$ & $105.3^{\mathrm{wx}}$ & $6.7^{\mathrm{a}-\mathrm{d}}$ & $82^{p-s}$ & $1.865^{\mathrm{j}-\mathrm{o}}$ & $0.23^{\mathrm{f}-\mathrm{n}}$ & $2.095^{\mathrm{i}-\mathrm{o}}$ \\
\hline 16 & Acc-16 & $4.2^{\mathrm{a}-\mathrm{f}}$ & $9.15^{\mathrm{lm}}$ & $19.72^{\mathrm{g}-1}$ & $2.45^{\mathrm{a}-\mathrm{d}}$ & $4.82^{\mathrm{fg}}$ & $32.6^{\mathrm{e}^{-\mathrm{g}}}$ & $158.1^{\mathrm{g}-\mathrm{i}}$ & $6.1^{\mathrm{b}-\mathrm{h}}$ & $150^{\mathrm{c}}$ & $3.84^{\mathrm{ab}}$ & $0.225^{\mathrm{f}-\mathrm{p}}$ & $4.1^{\mathrm{ab}}$ \\
\hline 17 & Acc-28336 & $4.2^{\mathrm{a}-\mathrm{f}}$ & $4.4^{\mathrm{wx}}$ & $13^{r-x}$ & $1.7^{\mathrm{k}}$ & $3.175^{\mathrm{k}-\mathrm{r}}$ & $41.1^{\mathrm{cd}}$ & $143^{\mathrm{k}-\mathrm{n}}$ & $4.7^{\mathrm{k}-\mathrm{p}}$ & $128^{\mathrm{e}}$ & $2.415^{\mathrm{d}-\mathrm{m}}$ & $0.16^{1-\mathrm{r}}$ & $2.58^{\mathrm{c}-\mathrm{n}}$ \\
\hline 18 & Acc- 230800 & $2.75^{\mathrm{n}-\mathrm{t}}$ & $6.55^{\mathrm{os}}$ & $11.94^{\mathrm{wx}}$ & $1.9^{c-k}$ & $3.395^{j-p}$ & $24.3^{1-\mathrm{n}}$ & $118.7^{\mathrm{sev}}$ & $6^{\mathrm{b}-\mathrm{i}}$ & $78.5^{\mathrm{q}-\mathrm{s}}$ & $2.49^{\mathrm{c}-\mathrm{m}}$ & $0.175^{\mathrm{j}-\mathrm{r}}$ & $2.7^{\mathrm{c}-\mathrm{n}}$ \\
\hline 19 & Acc- 28337 & $3.73^{\mathrm{d}-\mathrm{j}}$ & $7.03^{\mathrm{n}-\mathrm{p}}$ & $18.9 \mathrm{j}-\mathrm{n}$ & $2.13^{\mathrm{c}-\mathrm{j}}$ & $3.75^{\mathrm{h}-1}$ & $19^{\mathrm{o-r}}$ & $173.9^{\mathrm{e}}$ & $4.9^{j-p}$ & $83.5^{0-q}$ & $2.42^{\mathrm{d}-\mathrm{m}}$ & $0.15^{\mathrm{m}-\mathrm{r}}$ & $2.57^{\mathrm{c}-\mathrm{n}}$ \\
\hline 20 & Acc229699 & $3.25^{\mathrm{i}-\mathrm{o}}$ & $4.165^{\mathrm{wx}}$ & $23.8^{\mathrm{de}}$ & $2.36^{\mathrm{a}-\mathrm{f}}$ & $3.58^{\mathrm{h}-\mathrm{m}}$ & $42.9^{\mathrm{cd}}$ & $149.9^{\mathrm{i}-1}$ & $4.1^{\mathrm{op}}$ & $159.5^{\mathrm{b}}$ & $3.07^{\mathrm{b}-\mathrm{f}}$ & $0.125^{\mathrm{qr}}$ & $3.19^{\mathrm{c}-\mathrm{e}}$ \\
\hline 21 & Acc212912 & $4.25^{\mathrm{a}-\mathrm{e}}$ & $9.56^{\mathrm{j}-\mathrm{m}}$ & $31^{\mathrm{a}}$ & $2.7^{\mathrm{a}}$ & $6.82^{\mathrm{ab}}$ & $19.6^{\mathrm{n}-\mathrm{r}}$ & $231^{\mathrm{a}}$ & $6.8^{\mathrm{a}-\mathrm{c}}$ & $163^{\mathrm{ab}}$ & $4.16^{\mathrm{a}}$ & $0.33^{\mathrm{a}-\mathrm{e}}$ & $4.49^{\mathrm{a}}$ \\
\hline 22 & Acc-9097 & $4.5^{\mathrm{a}-\mathrm{c}}$ & $6.38^{o-u}$ & $16.8^{1-q}$ & $1.9^{\mathrm{g}-\mathrm{k}}$ & $1.815^{\mathrm{s}-\mathrm{u}}$ & $17.9^{\mathrm{qr}}$ & $101.1^{\mathrm{w}-\mathrm{y}}$ & $5.7^{\mathrm{d}-\mathrm{j}}$ & $61.5^{\mathrm{uv}}$ & $2.125^{\mathrm{g}-\mathrm{n}}$ & $0.125^{\mathrm{qr}}$ & $2.25^{\mathrm{f}-\mathrm{o}}$ \\
\hline 23 & Acc-9084 & $2.53^{\mathrm{q}-\mathrm{t}}$ & $5.25^{\mathrm{s}-\mathrm{x}}$ & $11.91^{\mathrm{wx}}$ & $1.75^{\mathrm{jk}}$ & $1.61^{\mathrm{tu}}$ & $42^{\mathrm{cd}}$ & $125.2^{\mathrm{rs}}$ & $5.1^{\mathrm{h}-\mathrm{n}}$ & $82.5^{0-\mathrm{r}}$ & $1.9^{\mathrm{i}-\mathrm{o}}$ & $0.23^{\mathrm{f}-\mathrm{n}}$ & $2.13^{\mathrm{h}-\mathrm{o}}$ \\
\hline 24 & Acc- 229697 & $3.8^{\mathrm{d}-\mathrm{j}}$ & $4.95^{v-x}$ & $14.91^{\mathrm{o}-\mathrm{w}}$ & $2^{\mathrm{e}-\mathrm{k}}$ & $1.82^{\mathrm{s}-\mathrm{u}}$ & $52^{\mathrm{ab}}$ & $93^{y}$ & $4^{p}$ & $83.5^{0-q}$ & $2.125^{\mathrm{g}-\mathrm{n}}$ & $0.315^{\mathrm{b}-\mathrm{f}}$ & $2.44^{\mathrm{d}-\mathrm{o}}$ \\
\hline 25 & Acc-212913 & $3^{1-\mathrm{s}}$ & $9.5^{\mathrm{k}-\mathrm{m}}$ & $18.63^{\mathrm{k}-\mathrm{n}}$ & $2.35^{\mathrm{a}-\mathrm{f}}$ & $5.98^{\mathrm{b}-\mathrm{d}}$ & $49.9^{b}$ & $118.3^{s-v}$ & $7.2^{\mathrm{a}}$ & $172.5^{\mathrm{a}}$ & $4.18^{\mathrm{a}}$ & $0.14^{\mathrm{n}-\mathrm{r}}$ & $4.32^{\mathrm{a}}$ \\
\hline 26 & Acc- 229700 & $3.57^{\mathrm{f}-\mathrm{m}}$ & $5.45^{q-x}$ & $11.855^{\mathrm{wx}}$ & $1.7^{\mathrm{k}}$ & $2.23^{\mathrm{q}-\mathrm{u}}$ & $54.9^{\mathrm{a}}$ & $128.1^{\mathrm{p}-\mathrm{s}}$ & $5.4^{\mathrm{e}-1}$ & $160^{\mathrm{b}}$ & $2.425^{\mathrm{c}-\mathrm{m}}$ & $0.22^{\mathrm{g}-\mathrm{q}}$ & $2.7^{\mathrm{c}-\mathrm{n}}$ \\
\hline 27 & Acc-8995 & $2.55^{\mathrm{p}-\mathrm{t}}$ & $4^{x}$ & $12.82^{1-x}$ & $1.85^{\mathrm{h}-\mathrm{k}}$ & $2.45^{\mathrm{p}-\mathrm{u}}$ & $43.65^{\mathrm{cd}}$ & $176^{\mathrm{e}}$ & $5.2^{\mathrm{g}-\mathrm{m}}$ & $99^{1-n}$ & $2.14^{\mathrm{g}-\mathrm{n}}$ & $0.38^{\mathrm{a}-\mathrm{c}}$ & $2.52^{\mathrm{c}-\mathrm{o}}$ \\
\hline 28 & Acc- 9085 & $3.2^{\mathrm{j}-\mathrm{p}}$ & $4.5^{\mathrm{wx}}$ & $11.86^{\mathrm{wx}}$ & $1.75^{\mathrm{jk}}$ & $2.31^{q-u}$ & $45.3^{\mathrm{c}}$ & $120^{\mathrm{r}-\mathrm{u}}$ & $4.9^{\mathrm{j}-\mathrm{p}}$ & $127.5^{\mathrm{e}}$ & $1.825^{\mathrm{j}-\mathrm{o}}$ & $0.115^{\mathrm{r}}$ & $1.94^{\mathrm{k}-\mathrm{p}}$ \\
\hline 29 & Acc 230798 & $3.94^{\mathrm{b}-\mathrm{h}}$ & $10.73^{\mathrm{f}-\mathrm{k}}$ & $27.75^{\mathrm{bc}}$ & $2.35^{\mathrm{a}-\mathrm{f}}$ & $3.935^{\mathrm{g}-\mathrm{k}}$ & $18.5^{\mathrm{p}-\mathrm{r}}$ & $142.35^{\mathrm{k}-\mathrm{n}}$ & $6.3^{\mathrm{a}-\mathrm{f}}$ & $72.5^{\mathrm{r}-\mathrm{t}}$ & $1.73^{\mathrm{k}-\mathrm{o}}$ & $0.115^{\mathrm{r}}$ & $1.845^{1-\mathrm{p}}$ \\
\hline 30 & Acc-230799 & $2.95^{\mathrm{m}-\mathrm{t}}$ & $5.3^{\mathrm{r}-\mathrm{x}}$ & $14.93^{\mathrm{o}-\mathrm{w}}$ & $1.95^{\mathrm{f}-\mathrm{k}}$ & $2.24^{q-u}$ & $31.6^{\mathrm{e}-\mathrm{h}}$ & $95.5^{y}$ & $5.2^{\mathrm{g}-\mathrm{m}}$ & $100^{\mathrm{k}-\mathrm{n}}$ & $1.675^{1-0}$ & $0.16^{1-\mathrm{r}}$ & $1.79^{\mathrm{m}-\mathrm{p}}$ \\
\hline 31 & Acc- 236436 & $3.02^{1-\mathrm{r}}$ & $6.45^{\text {o-u }}$ & $17.64^{\mathrm{k}-\mathrm{o}}$ & $2.69^{\mathrm{a}}$ & $2.61^{\mathrm{m}-\mathrm{u}}$ & $33.8^{\mathrm{ef}}$ & $99.3^{x y}$ & $6.3^{\mathrm{a}-\mathrm{f}}$ & $87^{0-q}$ & $2.29^{\mathrm{f}-\mathrm{m}}$ & $0.16^{1-\mathrm{r}}$ & $2.45^{\mathrm{e}-\mathrm{o}}$ \\
\hline 32 & Acc- 229698 & $3.35^{\mathrm{h}-\mathrm{n}}$ & $12.2^{\mathrm{d}-\mathrm{f}}$ & $23.25^{\mathrm{d}-\mathrm{f}}$ & $2.35^{\mathrm{a}-\mathrm{f}}$ & $4.35^{\mathrm{f}-\mathrm{j}}$ & $15.1^{\mathrm{r}}$ & $142.5^{\mathrm{k}-\mathrm{n}}$ & $6.3^{\mathrm{a}-\mathrm{f}}$ & $138^{\mathrm{d}}$ & $2.78^{\mathrm{c}-\mathrm{i}}$ & $0.115^{\mathrm{r}}$ & $2.9^{c-j}$ \\
\hline 33 & Acc-229701 & $3.05^{\mathrm{k}-\mathrm{r}}$ & $4.05^{\mathrm{wx}}$ & $12.1^{\mathrm{u}-\mathrm{x}}$ & $1.85^{\mathrm{h}-\mathrm{k}}$ & $2.125^{\mathrm{r}-\mathrm{u}}$ & $52.25^{\mathrm{ab}}$ & $126.7^{q-s}$ & $4.9^{\mathrm{j}-\mathrm{p}}$ & $126^{\mathrm{e}}$ & $2.56^{\mathrm{c}-1}$ & $0.21^{\mathrm{h}-\mathrm{r}}$ & $2.77^{\mathrm{c}-\mathrm{k}}$ \\
\hline 34 & Acc- 237528 & $2.29^{t}$ & $4.93^{\mathrm{u}-\mathrm{x}}$ & $15.12^{\text {o-u }}$ & $2.05^{\mathrm{d}-\mathrm{k}}$ & $2.36^{p-u}$ & $30.3^{\mathrm{e}-\mathrm{j}}$ & $144.5^{\mathrm{k}-\mathrm{n}}$ & $4.4^{1-p}$ & $56^{v}$ & $1.7^{1-\mathrm{o}}$ & $0.35^{\mathrm{a}-\mathrm{d}}$ & $2.04^{j-p}$ \\
\hline 35 & Acc-9102 & $3.9^{\mathrm{c}-\mathrm{i}}$ & $6.1^{\mathrm{o}-\mathrm{v}}$ & $16.96^{1-p}$ & $1.95^{\mathrm{f}-\mathrm{k}}$ & $2.435^{p-u}$ & $26.9^{\mathrm{h}-\mathrm{m}}$ & $151.2^{\mathrm{i}-\mathrm{k}}$ & $4.3^{\mathrm{m}-\mathrm{p}}$ & $64^{t-v}$ & $0.7^{\mathrm{p}}$ & $0.13^{\mathrm{p}-\mathrm{r}}$ & $0.83^{\mathrm{q}}$ \\
\hline 36 & Acc-9094 & $2.3^{t}$ & $6.9^{\mathrm{n}-\mathrm{q}}$ & $19.23^{\mathrm{i}-\mathrm{m}}$ & $1.8^{\mathrm{i}-\mathrm{k}}$ & $2.63^{\mathrm{m}-\mathrm{t}}$ & $24.5^{\mathrm{k}-\mathrm{n}}$ & $150.3^{\mathrm{i}-1}$ & $4.7^{\mathrm{k}-\mathrm{p}}$ & $98^{1-n}$ & $2.08^{\mathrm{h}-\mathrm{m}}$ & $0.165^{1-\mathrm{r}}$ & $2.25^{\mathrm{f}-\mathrm{o}}$ \\
\hline 37 & Acc- 9098 & $3^{1-s}$ & $5.3^{r-x}$ & $11.84^{\mathrm{wx}}$ & $1.85^{\mathrm{h}-\mathrm{k}}$ & $2.22^{q-u}$ & $39^{d}$ & $123.5^{\mathrm{r}-\mathrm{t}}$ & $5.4 \mathrm{e}-1$ & $80.5^{\mathrm{q}-\mathrm{s}}$ & $1.71^{\mathrm{k}-\mathrm{o}}$ & $0.35^{\mathrm{a}-\mathrm{d}}$ & $2.1^{\mathrm{i}-\mathrm{p}}$ \\
\hline 38 & Acc-9104 & $2.75^{\mathrm{n}-\mathrm{t}}$ & $5.2^{\mathrm{s}-\mathrm{x}}$ & $15.19^{\text {o-u }}$ & $1.8^{\mathrm{i}-\mathrm{k}}$ & $2.31^{q-u}$ & $28.2^{\mathrm{g}-1}$ & $110.8^{\mathrm{u}-\mathrm{w}}$ & $4.9^{\mathrm{j}-\mathrm{p}}$ & $79^{\mathrm{q}-\mathrm{s}}$ & $2.065^{\mathrm{h}-\mathrm{n}}$ & $0.265^{\mathrm{d}-\mathrm{j}}$ & $2.33^{\mathrm{e}-\mathrm{o}}$ \\
\hline 39 & Acc-9099 & $3.1^{\mathrm{k}-\mathrm{r}}$ & $4.3^{\mathrm{wx}}$ & $12.2^{\mathrm{u}-\mathrm{x}}$ & $1.8^{\mathrm{i}-\mathrm{k}}$ & $2.235^{\mathrm{q}-\mathrm{u}}$ & $22.1^{\mathrm{m}-\mathrm{q}}$ & $150.4^{\mathrm{i}-1}$ & $4^{p}$ & $64^{t-v}$ & $1.395^{\mathrm{n}-\mathrm{p}}$ & $0.26^{\mathrm{d}-\mathrm{k}}$ & $1.66^{\mathrm{op}}$ \\
\hline 40 & Acc- 9082 & $3.95^{\mathrm{b}-\mathrm{h}}$ & $6.8^{\mathrm{o}-\mathrm{r}}$ & $21.75^{\mathrm{e}-\mathrm{j}}$ & $2.1^{\mathrm{d}-\mathrm{k}}$ & $2.72^{1-s}$ & $24^{1-0}$ & $139^{\mathrm{m}-\mathrm{o}}$ & $5.3^{\mathrm{f}-\mathrm{m}}$ & $89.5^{\mathrm{n}-\mathrm{q}}$ & $2.53^{\mathrm{c}-1}$ & $0.175^{\mathrm{j}-\mathrm{r}}$ & $2.71^{\mathrm{c}-1}$ \\
\hline 41 & Acc-9101 & $3.19^{\mathrm{j}-\mathrm{q}}$ & $4.3^{\mathrm{wx}}$ & $12.84^{t-x}$ & $1.75^{\mathrm{jk}}$ & $2.245^{\mathrm{q}-\mathrm{u}}$ & $42.9^{\mathrm{cd}}$ & $170.1^{\text {ef }}$ & $4.1^{\mathrm{op}}$ & $84^{0-q}$ & $2.555^{\mathrm{c}-1}$ & $0.155^{1-\mathrm{r}}$ & $2.71^{\mathrm{c}-1}$ \\
\hline 42 & Acc-9086 & $4^{a-h}$ & $5.4^{r-x}$ & $17.82^{\mathrm{k}-\mathrm{o}}$ & $1.99^{\mathrm{e}-\mathrm{k}}$ & $2.57^{\mathrm{m}-\mathrm{u}}$ & $42.2^{\mathrm{cd}}$ & $137.9^{\mathrm{m}-\mathrm{p}}$ & $4.1^{\mathrm{op}}$ & $99^{1-n}$ & $2.4^{\mathrm{d}-\mathrm{m}}$ & $0.39^{\mathrm{ab}}$ & $2.79^{\mathrm{c}-\mathrm{k}}$ \\
\hline 43 & Acc229696 & $2.35^{\text {st }}$ & $4.18^{w x}$ & $12.79^{s-x}$ & $1.75^{\mathrm{jk}}$ & $2.71^{1-s}$ & $42.5^{\mathrm{cd}}$ & $99.7^{x y}$ & $4.3^{\mathrm{m}-\mathrm{p}}$ & $92^{\mathrm{m}-\mathrm{p}}$ & $2.1^{\mathrm{g}-\mathrm{n}}$ & $0.31^{\mathrm{b}-\mathrm{g}}$ & $2.41^{\mathrm{d}-\mathrm{o}}$ \\
\hline 44 & Acc-9106 & $4.04^{\mathrm{a}-\mathrm{g}}$ & $6.51^{0-t}$ & $16.54^{\mathrm{m}-\mathrm{q}}$ & $1.95^{\mathrm{f}-\mathrm{k}}$ & $2.235^{\mathrm{q}-\mathrm{u}}$ & $32^{\mathrm{e}-\mathrm{g}}$ & $138.9^{\mathrm{m}-\mathrm{o}}$ & $4.4^{1-p}$ & $71.5^{\mathrm{s}-\mathrm{u}}$ & $2.1^{\mathrm{h}-\mathrm{m}}$ & $0.13^{\mathrm{p}-\mathrm{r}}$ & $2.21^{\mathrm{g}-\mathrm{o}}$ \\
\hline 45 & Acc-9007 & $3.69^{\mathrm{d}-\mathrm{k}}$ & $4.22^{\mathrm{wx}}$ & $15.9^{\mathrm{n}-\mathrm{s}}$ & $1.75^{\mathrm{jk}}$ & $2.495^{\mathrm{n}-\mathrm{u}}$ & $31.3^{\mathrm{e}-\mathrm{i}}$ & $156^{\mathrm{h}-\mathrm{j}}$ & $5^{\mathrm{i}-\mathrm{o}}$ & $115^{\mathrm{f}-\mathrm{i}}$ & $2.035^{\mathrm{h}-\mathrm{n}}$ & $0.37^{\mathrm{a}-\mathrm{c}}$ & $2.4^{\mathrm{d}-\mathrm{o}}$ \\
\hline 46 & Acc-9107 & $4.6^{\mathrm{ab}}$ & $10.97^{\mathrm{e}-\mathrm{k}}$ & $23.88^{\mathrm{de}}$ & $2.25^{\mathrm{b}-\mathrm{h}}$ & $3.21^{\mathrm{k}-\mathrm{q}}$ & $16.6^{\mathrm{r}}$ & $128.9^{0-\mathrm{r}}$ & $5.2^{\mathrm{g}-\mathrm{m}}$ & $82.5^{0-\mathrm{r}}$ & $2.41^{\mathrm{d}-\mathrm{m}}$ & $0.125^{\mathrm{qr}}$ & $2.53^{\mathrm{c}-\mathrm{o}}$ \\
\hline 47 & Acc-28334 & $4.25^{\mathrm{a}-\mathrm{e}}$ & $14.7^{\mathrm{b}}$ & $25.24^{\mathrm{cd}}$ & $2.4^{\mathrm{a}-\mathrm{e}}$ & $6^{\mathrm{b}-\mathrm{d}}$ & $19.6^{\mathrm{n}-\mathrm{r}}$ & $186.8^{\mathrm{d}}$ & $5.7^{\mathrm{d}-\mathrm{j}}$ & $120^{\mathrm{e}-\mathrm{h}}$ & $2.6^{\mathrm{c}-\mathrm{k}}$ & $0.125^{\mathrm{qr}}$ & $2.73^{\mathrm{c}-1}$ \\
\hline 48 & Acc- 48 & $4.25^{\mathrm{a}-\mathrm{e}}$ & $11.4^{\mathrm{d}-\mathrm{i}}$ & $25.18^{\mathrm{cd}}$ & $2.57^{\mathrm{ab}}$ & $5.77^{\mathrm{c}-\mathrm{e}}$ & $19^{0-\mathrm{r}}$ & $200.9^{c}$ & $5.7^{\mathrm{d}-\mathrm{j}}$ & $121.5^{\mathrm{e}-\mathrm{g}}$ & $2.57^{\mathrm{c}-1}$ & $0.13^{\mathrm{p}-\mathrm{r}}$ & $2.7^{\mathrm{c}-\mathrm{m}}$ \\
\hline 49 & Acc-49 & $4.3^{\mathrm{a}-\mathrm{d}}$ & $12.5^{\mathrm{c}-\mathrm{e}}$ & $25.1^{\mathrm{cd}}$ & $2.4^{\mathrm{a}-\mathrm{e}}$ & $7.1^{\mathrm{a}}$ & $15.2^{\mathrm{r}}$ & $142.3^{1-n}$ & $6^{\mathrm{b}-\mathrm{i}}$ & $144^{\mathrm{cd}}$ & $2.865^{\mathrm{c}-\mathrm{h}}$ & $0.2^{\mathrm{i}-\mathrm{r}}$ & $3.1^{\mathrm{c}-\mathrm{g}}$ \\
\hline 50 & Acc-229694 & $4.27^{\mathrm{a}-\mathrm{e}}$ & $13.78^{\mathrm{bc}}$ & $24.56^{\mathrm{de}}$ & $2.35^{\mathrm{a}-\mathrm{f}}$ & $6.19^{\mathrm{a}-\mathrm{d}}$ & $17.6^{\mathrm{qr}}$ & $139.3^{\mathrm{mn}}$ & $6.9^{\mathrm{ab}}$ & $112^{g-j}$ & $2.92^{\mathrm{chh}}$ & $0.115^{\mathrm{r}}$ & $3.03^{\mathrm{c}-\mathrm{h}}$ \\
\hline 51 & Acc-51 & $3.9^{\mathrm{c}-\mathrm{i}}$ & $12.5^{\mathrm{c}-\mathrm{e}}$ & $29.45^{\mathrm{ab}}$ & $2.55^{\mathrm{a}-\mathrm{c}}$ & $5.32^{\mathrm{d}-\mathrm{f}}$ & $18.75^{\mathrm{pr}}$ & $166.4^{\mathrm{e}-\mathrm{g}}$ & $6.3^{\mathrm{a}-\mathrm{f}}$ & $105.5^{\mathrm{i}-\mathrm{l}}$ & $2.14^{g-n}$ & $0.16^{1-\mathrm{r}}$ & $2.3^{\mathrm{e}-\mathrm{o}}$ \\
\hline 52 & Acc-52 & $3.2^{\mathrm{j}-\mathrm{p}}$ & $12.65^{\mathrm{cd}}$ & $19.4^{\mathrm{h}-\mathrm{m}}$ & $2.21^{\mathrm{b}-\mathrm{i}}$ & $4.37^{\mathrm{f}-\mathrm{j}}$ & $15.6^{\mathrm{r}}$ & $142.8^{\mathrm{k}-\mathrm{n}}$ & $5.4^{\mathrm{e}-1}$ & $82.5^{0-\mathrm{r}}$ & $1.1^{\mathrm{op}}$ & $0.115^{\mathrm{r}}$ & $1.2^{\mathrm{pq}}$ \\
\hline 53 & Acc- 9093 & $3.625^{\mathrm{e}-1}$ & $11.32^{\mathrm{d}-\mathrm{i}}$ & $20.54^{\mathrm{f}-\mathrm{k}}$ & $2.15^{\mathrm{b}-\mathrm{j}}$ & $6.27^{\mathrm{a}-\mathrm{d}}$ & $24.1^{1-0}$ & $145^{\mathrm{k}-\mathrm{n}}$ & $6.8^{\mathrm{a}-\mathrm{c}}$ & $140.5^{\text {cd }}$ & $3.34^{\mathrm{bc}}$ & $0.115^{\mathrm{r}}$ & $3.43^{\mathrm{bc}}$ \\
\hline 54 & Acc- 229692 & $3.84^{\mathrm{c}-\mathrm{j}}$ & $12.45^{\mathrm{ce} e}$ & $18.92^{\mathrm{j}-\mathrm{n}}$ & $2.2^{\mathrm{b}-\mathrm{i}}$ & $3.175^{\mathrm{k}-\mathrm{r}}$ & $27.9^{\mathrm{g}-1}$ & $125.4^{\mathrm{r}-\mathrm{t}}$ & $6.8^{\mathrm{a}-\mathrm{c}}$ & $81.5^{\mathrm{p}-\mathrm{s}}$ & $2.795^{\mathrm{c}-\mathrm{i}}$ & $0.17^{\mathrm{k}-\mathrm{q}}$ & $3^{\mathrm{c}-\mathrm{i}}$ \\
\hline 55 & Acc-55 & $4.65^{\mathrm{a}}$ & $11.68^{\mathrm{d}-\mathrm{h}}$ & $22.43^{\mathrm{d}-\mathrm{g}}$ & $2.25^{\mathrm{b}-\mathrm{h}}$ & $4.585^{\mathrm{fh}}$ & $19^{o-r}$ & $152^{i-k}$ & $5.4^{\mathrm{e}-1}$ & $93^{\mathrm{m}-\mathrm{o}}$ & $2.47^{\mathrm{c}-\mathrm{m}}$ & $0.12^{\mathrm{r}}$ & $2.59^{\mathrm{c}-\mathrm{n}}$ \\
\hline 56 & Acc-56 & $4.02^{\mathrm{a}-\mathrm{g}}$ & $11.6^{\mathrm{d}-\mathrm{h}}$ & $22.35^{\mathrm{d}-\mathrm{h}}$ & $2.2^{\mathrm{b}-\mathrm{i}}$ & $4.98^{\mathrm{ef}}$ & $14.85^{\mathrm{r}}$ & $138^{\mathrm{m}-\mathrm{p}}$ & $6.7^{\mathrm{a}-\mathrm{d}}$ & $100^{\mathrm{k}-\mathrm{n}}$ & $2.22^{\mathrm{f}-\mathrm{n}}$ & $0.14^{\mathrm{n}-\mathrm{r}}$ & $2.36^{\mathrm{d}-\mathrm{o}}$ \\
\hline 57 & Acc-57 & $3.95^{\mathrm{b}-\mathrm{h}}$ & $11.27^{\mathrm{d}-\mathrm{i}}$ & $21.97^{\mathrm{e}-\mathrm{i}}$ & $2.25^{\mathrm{b}-\mathrm{h}}$ & $5.79^{\mathrm{c}-\mathrm{e}}$ & $14.75^{\mathrm{r}}$ & $174.4^{\mathrm{e}}$ & $6.5^{\mathrm{a}-\mathrm{d}}$ & $167.5^{\mathrm{ab}}$ & $3.1^{\mathrm{b}-\mathrm{f}}$ & $0.165^{1-\mathrm{r}}$ & $3.26^{\mathrm{b}-\mathrm{d}}$ \\
\hline 58 & Acc-58 & $3.925^{\mathrm{c}-\mathrm{h}}$ & $9.93^{\mathrm{i}-1}$ & $19.75^{\mathrm{g}-1}$ & $2.2^{\mathrm{b}-\mathrm{i}}$ & $4.47^{\mathrm{f}-\mathrm{i}}$ & $18.3^{\mathrm{p}-\mathrm{r}}$ & $161.4^{\mathrm{f}-\mathrm{h}}$ & $6.9^{\mathrm{ab}}$ & $138.5^{\mathrm{d}}$ & $2.83^{\mathrm{chh}}$ & $0.14^{\mathrm{n}-\mathrm{r}}$ & $2.97^{\mathrm{c}-\mathrm{i}}$ \\
\hline 59 & Acc-59 & $2.42^{r-t}$ & $5.62^{\mathrm{r}-\mathrm{w}}$ & $13.7^{q-x}$ & $1.8^{\mathrm{i}-\mathrm{k}}$ & $2.61^{\mathrm{m}-\mathrm{u}}$ & $53.5 \mathrm{ab}$ & $139^{\mathrm{m}-\mathrm{o}}$ & $6.2^{\mathrm{a}-\mathrm{g}}$ & $125^{\mathrm{ef}}$ & $2.49^{\mathrm{c}-\mathrm{m}}$ & $0.3^{c-h}$ & $2.78^{\mathrm{c}-\mathrm{k}}$ \\
\hline 60 & Acc- 23880 & $3.86^{\mathrm{c}-\mathrm{i}}$ & $11.18^{\mathrm{d}-\mathrm{i}}$ & $22.2^{\mathrm{d}-\mathrm{h}}$ & $2.15^{\mathrm{b}-\mathrm{j}}$ & $4.58^{\mathrm{f}-\mathrm{h}}$ & $15.2^{\mathrm{r}}$ & $135.3^{\mathrm{n}-\mathrm{q}}$ & $6.6^{\mathrm{a}-\mathrm{d}}$ & $112.5^{\mathrm{g}-\mathrm{j}}$ & $2.515^{\mathrm{c}-\mathrm{m}}$ & $0.125^{\mathrm{qr}}$ & $2.64^{\mathrm{c}-\mathrm{n}}$ \\
\hline 61 & Acc-61 & $2.9^{n-t}$ & $11.85^{\mathrm{d}-\mathrm{g}}$ & $22.68^{\mathrm{d}-\mathrm{g}}$ & $2.3^{\mathrm{a}-\mathrm{g}}$ & $6.7^{\mathrm{a}-\mathrm{c}}$ & $16.2^{\mathrm{r}}$ & $145.4^{\mathrm{k}-\mathrm{n}}$ & $5.7^{\mathrm{d}-\mathrm{j}}$ & $161^{\mathrm{b}}$ & $2.995^{\mathrm{c}-\mathrm{g}}$ & $0.16^{1-\mathrm{r}}$ & $3.16^{\mathrm{c}-\mathrm{f}}$ \\
\hline
\end{tabular}




\begin{tabular}{|c|c|c|c|c|c|c|c|c|c|c|c|c|c|}
\hline 62 & Acc-62 & $4.5^{-\mathrm{acc}}$ & $12.05^{d-f}$ & $18.48^{k-n}$ & $2.2^{\mathrm{b}-\mathrm{i}}$ & $6.1^{\mathrm{b}-\mathrm{d}}$ & $19.6^{\mathrm{n}-\mathrm{r}}$ & $140.5^{1-\mathrm{n}}$ & $6.6^{\mathrm{a}-\mathrm{d}}$ & $105^{\mathrm{i}-1}$ & $3.245^{\mathrm{b}-\mathrm{e}}$ & $0.165^{1-\mathrm{r}}$ & $3.41^{\mathrm{bc}}$ \\
\hline 63 & Acc-63 & $4^{a-h}$ & $10.4^{g-1}$ & $13.27^{-\mathrm{x}}$ & $2.05^{\mathrm{d}-\mathrm{k}}$ & $3.46^{-0}$ & $30.6^{\mathrm{c}-\mathrm{j}}$ & $128.4^{p-s}$ & $4.4^{1-\mathrm{p}}$ & $110^{\mathrm{h}-\mathrm{k}}$ & $2.43^{\mathrm{c}-\mathrm{m}}$ & $0.125^{\mathrm{ar}}$ & $2.56^{\mathrm{co}}$ \\
\hline \multirow[t]{3}{*}{64} & Acc-64 & $3.94^{\mathrm{b}-\mathrm{h}}$ & $10.28^{\mathrm{h}-1}$ & $19.71^{\mathrm{g}-1}$ & $1.95^{\mathrm{f-k}}$ & $3.5^{\mathrm{in} \mathrm{n}}$ & $19.25^{-\mathrm{or}}$ & $137.9^{\mathrm{m}-\mathrm{p}}$ & $5.7^{\mathrm{d}-\mathrm{j}}$ & $80^{\mathrm{q}-\mathrm{s}}$ & $2.35^{\mathrm{e}-\mathrm{m}}$ & $0.185^{\mathrm{j}-\mathrm{r}}$ & $2.54^{c-0}$ \\
\hline & Mean & 3.5 & 8 & 18 & 2.1 & 3.6 & 31 & 139.1 & 5.6 & 107.3 & 2.48 & 0.19 & 2.67 \\
\hline & CV (\%) & 7.8 & 7.8 & 7.1 & 8.3 & 11.9 & 6.9 & 3.1 & 7.8 & 4.2 & 14.6 & 19.7 & 13.8 \\
\hline
\end{tabular}

Means followed by the same letter in the same column are not significantly different. CV $(\%)=$ coefficient of variation, $\mathrm{FPL}=$ fruit pedicel length, $\mathrm{FL}=$ fruit length, $\mathrm{FD}=$ fruit diameter, $\mathrm{FPT}=$ fruit pericarp thickness, $\mathrm{FW}=$ average single fruit weight, NFP = number of fruits per plant, NSF = number of seeds per fruit, DFYP=dry fruit yield per plant, MFY $=$ marketable fruit yield, $\mathrm{UNMFY}=\mathrm{Unmarketable}$ fruit yield, $\mathrm{TFY}=$ total fruit yield .

\section{Copyrights}

Copyright for this article is retained by the author(s), with first publication rights granted to the journal.

This is an open-access article distributed under the terms and conditions of the Creative Commons Attribution license (http://creativecommons.org/licenses/by/4.0/). 